\title{
Epistemic Teleology and the Separateness of Propositions
}

\section{Citation}

Berker, S. 2013. "Epistemic Teleology and the Separateness of Propositions."

Philosophical Review 122 (3) (August 2): 337-393. doi:10.1215/00318108-2087645. http:// dx.doi.org/10.1215/00318108-2087645.

\section{Published Version}

doi:10.1215/00318108-2087645

\section{Permanent link}

http://nrs.harvard.edu/urn-3:HUL.InstRepos:23990497

\section{Terms of Use}

This article was downloaded from Harvard University's DASH repository, and is made available under the terms and conditions applicable to Open Access Policy Articles, as set forth at http:// nrs.harvard.edu/urn-3:HUL.InstRepos:dash.current.terms-of-use\#OAP

\section{Share Your Story}

The Harvard community has made this article openly available.

Please share how this access benefits you. Submit a story.

Accessibility 


\title{
Epistemic Teleology and the Separateness of Propositions
}

\author{
Selim Berker \\ Harvard University \\ sberker@fas.harvard.edu
}

[Penultimate draft of a paper that was eventually published in Philosophical Review 122 (2013): 337-393; please cite that version.]

\begin{abstract}
When it comes to epistemic normativity, should we take the good to be prior to the right? That is, should we ground facts about what we ought and ought not believe on a given occasion in facts about the value of being in certain cognitive states (such as, for example, the value of having true beliefs)? The overwhelming answer among contemporary epistemologists is: "Yes, we should." In this essay I argue to the contrary. Just as taking the good to be prior to the right in ethics often leads one to sanction implausible trade-offs when determining what an agent should do, so too, I argue, taking the good to be prior to the right in epistemology leads one to sanction implausible tradeoffs when determining what a subject should believe. Epistemic value - and, by extension, epistemic goals - are not the explanatory foundation upon which all other normative notions in epistemology rest.
\end{abstract}

\section{Introduction}

As I see it, the most fundamental question in ethics is "What should I do?"1 The exact wording of this question can take different forms, depending on one's normative vocabulary of choice ("What do I have most reason to do?," "What is it rational for me to do?," "What am I justified in doing?"). And the question can take broader or narrower scope, depending on whether it is applied to a specific situation ("Should I tell her the truth?") or to one's life as a whole ("What sort of a life should I live?"). One branch of ethics - metaethics - seeks to clarify this fundamental question, in its many different manifestations. What does the question mean? What would constitute an answer to it? How can we go about figuring out that answer? What would the objective status of such an answer be, were we able to find one? The other branch of ethics - normative ethics - offers substantive answers to our fundamental question, in its various guises. Sometimes these answers take the form of grand theories that distill should-be-done-ness down to a pristine set of necessary and sufficient conditions - the familiar conflicting "-isms" of introductory ethics courses (egoism, utilitarianism, Kantianism, contractualism, and the like). Other times these answers are more modest in scale, taking the form of a mid-level principle such as the doctrine of double effect, or even just a particular verdict about a particular scenario.

1 More accurately, the fundamental question in ethics is "What, if anything, should I do?," to allow for the possibility that there is no such thing as should-be-done-ness. Since I will not be broaching the subject of normative nihilism in the current essay, I leave this complication to one side. 
I think it is useful to view epistemology as having a parallel structure. On this way of conceiving of the discipline, the most fundamental question in epistemology is "What should I believe?" The exact wording of this question can take different forms, depending on one's normative vocabulary of choice ("What do I have most reason to believe?," "What is it rational for me to believe?," "What am I justified in believing?"). And the question can take broader or narrower scope, depending on whether it is applied to a specific proposition ("Should I believe that there is a God?") or to one's cognitive life as a whole ("How should I go about forming my beliefs?"). One branch of epistemology - metaepistemology, as we might call it - seeks to clarify this fundamental question, in its many different manifestations. The other branch of epistemology - normative epistemology, if you will-offers substantive answers to our fundamental question, in its various guises, resulting in the familiar conflicting "-isms" from introductory epistemology courses (Cartesian foundationalism, coherentism, reliabilism, and the like).

Now this way of viewing epistemology is controversial. For instance, many contemporary epistemologists frame their fundamental question in the third person: "What is he or she justified in believing?," not "What am I justified in believing?" Recently, a growing number of epistemologists have emphasized the social nature of epistemic norms: they ask, in effect, "What do we have most reason to believe?" And, most controversially, my way of characterizing the field of epistemology seems to blatantly disregard its etymological origins as "the study (-ology) of knowledge (epistemmē)": for many epistemologists, the fundamental question in epistemology is "What makes a belief count as knowledge?" I think each of these alternate epistemological questions is important in its own right, but I regard them as auxiliary questions that can be addressed only after significant headway has been made on the more fundamental question "What should I believe?"- - although I realize that, in saying this, I am making a bold claim that I can't hope to defend here.

One virtue of viewing epistemology in the manner I have been proposing is that it brings to the fore the normative character of the discipline. Moreover, I think that exploring the analogy between ethics and epistemology can help us make progress in both fields. But this thought is compatible with recognizing that, in the end, the tempting parallelism between ethics and epistemology may turn out to be partially illusory. The surface similarity of the questions "What should I do?" and "What should I 
believe?" might mask a deeper divide between what is really being asked by these questions, and what a proper answer to them involves; that is, our metaethics might end up looking very different from our metaepistemology, and our normative ethics might end up looking very different from our normative epistemology. Indeed, I think this result is almost inevitable, at least to a certain degree. After all, belief is not action, and action is not belief. So at some point the analogy between ethics and epistemology must break down. However, the ethics-epistemology analogy is not alone in this regard. All analogies break down at some point; that's what makes them analogies and not identities. So even if we must be careful not to push it too far, the ethics-epistemology analogy can, I think, do real work for us.

In what follows, I want to use this analogy between normative evaluations of actions and normative evaluations of beliefs to tease out, and then argue against, a certain strain of thought that seems to have become an article of faith in much recent epistemological theorizing. According to this strain of thought, what distinguishes epistemic norms from other sorts of norms (prudential, moral, and so on) is that epistemic norms are guided by a distinctive set of "epistemic" or "cognitive" or "intellectual" goals. Most often these epistemic goals are taken to be the twin goals of acquiring true beliefs and avoiding false ones. Sometimes, though, the list of epistemic goals is broadened to include other items, such as the acquisition of knowledge, or coherent belief-systems, or understanding, or wisdom. But regardless of what the list of epistemic goals looks like, the guiding idea behind this strain of thought is that all other normative notions in epistemology are ultimately explicable in terms of how well the objects of assessment conduce toward, promote, or otherwise subserve these epistemic goals.

In a way, this picture is a very natural one, which perhaps explains why it is so widely endorsed (and almost always without being explicitly argued for). However, by thinking about the analogy between ethics and epistemology, we can at once see the degree to which this picture has some quite substantial normative assumptions built into it. According to this picture, there are certain epistemic ends or goals that it is epistemically good for us to promote, and the question of what we should believe is determined by how well our believing conduces toward the fulfilling of those goals, or the furthering of those ends. But this, of course, is the analogue in normative epistemology of consequentialist or teleological approaches to normative ethics: it makes the good prior to the right with regard to the epistemic evaluation of beliefs, just as 
consequentialist/teleological ethical systems are often characterized as making the good prior to the right with regard to the ethical evaluation of actions. Maybe, in the end, such an approach is justified. But it is hardly an innocent starting point for epistemological theorizing that can just be assumed without argument.

Indeed, my aim in this essay is to convince you of something stronger. I want to convince you that this consequentialist/teleological approach to normative epistemology is positively misguided — that is, I want to convince you that, when providing a substantive answer to the question "What should I believe?" or "What am I justified in believing?," we should not proceed by first identifying certain epistemic goods, and then constructing a theory of epistemic justification in terms of what conduces toward or promotes those epistemic goods. My basic argument will be relatively simple. Consequentialist/teleological theories in ethics have a certain structure: in particular, they almost always countenance trade-offs between various goods in the determination of which action should be done. So if the consequentialist/teleological approach to normative epistemology were the correct one, we'd expect that the correct theory of what we should believe would also countenance trade-offs between goods - in this case, trade-offs between epistemic goods. However, no one- not even those epistemologists who most explicitly embrace the consequentialist/teleological framework - is willing to countenance all such trade-offs in the epistemic case. So, I will conclude, this entire approach to normative epistemology is misguided: its advocates don't realize what their approach really commits them to, and if they did realize it, they would abandon the approach rather than incorporate the commitment. Fully defending this conclusion, though, will take a bit of care since modern consequentialists have developed a variety of techniques for including bans on at least certain types of trade-offs within a broadly consequentialist ethical framework. Thus I will need to argue that none of these techniques can be employed in the epistemic case - or that if they can be employed, then they don't succeed in prohibiting the sorts of epistemic trade-offs that, I will argue, nearly everyone deems to be unacceptable.

First, though, we should be a bit more precise about what, exactly, a consequentialist or teleological approach involves, whether in the case of ethics or epistemology. 


\section{Ethical Teleology and Epistemic Teleology}

Modern introductory courses in normative ethics tend to have a familiar narrative: the titanic clash between deontological and consequentialist moral theories. On the consequentialist side, one studies actutilitarianism, non-utilitarian varieties of act-consequentialism, and (if there's time) rule-consequentialism. On the deontological side, one studies various formulations of Kant's categorical imperative, Ross's theory of prima facie duties, and (if there's time) contractualism. The familiar refrain is that consequentialist theories define the right in terms of the good, whereas deontological theories reverse that order of explanation.

This division of all ethical theories into two general categories depending on their stand on the explanatory priority of goodness/betterness/value versus rightness/obligation/duty appears to have been a staple of most twentieth-century ethics courses in the analytic tradition, if introductory textbooks and anthologies are any guide. The slightly older term for much the same distinction was "teleological" (from the Greek telos for 'end') versus "deontological” (from the Greek deon for 'duty') ethical theories. This terminology was introduced as a way of partitioning all ethical theories into two groups by C. D. Broad in $1930,{ }^{2}$ and most ethics textbooks and anthologies from the 1940s, 1950s, and 1960s that are written in English follow Broad's taxonomy. ${ }^{3}$ However, the basic distinction appears to predate Broad. For example, in their textbook Ethics from 1908, John Dewey and James H. Tufts (1908, 224-25) call moral theories that take value or goodness as their fundamental idea "teleological" and moral theories that take duty or rightness as their fundamental idea "jural" (from the Latin jus for 'law'). Moreover, the manner in which Dewey and Tufts write suggests that this division was not their own creation, but rather one that was

2 "I would first divide ethical theories into two classes, which I will call respectively deontological and teleological. / Deontological theories hold that there are ethical propositions of the form: 'Such and such a kind of action would always be right (or wrong) in such and such circumstances, no matter what its consequences might be'... Teleological theories hold that the rightness or wrongness of an action is always determined by its tendency to produce certain consequences which are intrinsically good or bad" (Broad 1930, 206-7). Also responsible for popularizing this use of 'teleological' and 'deontological' was J. H. Muirhead (1932, 6), who in his book Rule and End in Morals used these words to characterize two opposing "points of view" in ethics. (Note that 'teleological' and 'deontological' had somewhat different meanings in ethics before Broad's and Muirhead's use of them became standard; in fact, 'deontology' began its lexical life as Jeremy Bentham's name for what I will call a teleologist's deontic theory. For discussion, see Louden 1996.)

3 See, for example, Tsanoff 1947, 38-41; Garvin 1953, 193; Brandt 1961, 131-32; Zink 1962, 154; Frankena 1963, 13-14; and Banner 1968, 167. (Tsanoff and Garvin use 'formalism' instead of 'deontology' as the contrast term for 'teleological ethics', whereas Brandt uses both 'formalism' and 'deontology', which for him are synonyms.) 
common at the time their book was published. ${ }^{4}$

In her essay "Modern Moral Philosophy" from 1958, Elizabeth Anscombe (1958, 12) introduced the term 'consequentialism', 5 and gradually during the latter half of the twentieth century 'consequentialist' came to replace 'teleological' as the chief designator of the sort of ethical theory that is said to contrast with deontological ones. But despite the current ubiquity of the term 'consequentialism', in this essay I will primarily be using the pre-Anscombian term 'teleology' to refer to the type of ethical and epistemic theories under consideration. My main reason for doing so is that the phrase 'epistemic consequentialism' is liable to cause confusion in a way that the phrase 'epistemic teleology' does not. 'Epistemic consequentialism' suggests a theory according to which whether a belief is justified or unjustified depends on the non-epistemic goodness or badness of the consequences of believing it; however, that's not the sort of theory defended by the people who are the target of my discussion here. 'Epistemic teleology', on the other hand, more aptly captures the sort of position in normative epistemology that I aim to criticize: namely, an epistemic theory that is structurally parallel to teleological/consequentialist theories in normative ethics, not one that is an instance of such an ethical theory.

Providing a precise characterization of the teleological/deontological distinction is difficult to do. Nearly everyone agrees that hedonistic act-utilitarianism is a canonical example of a teleological ethical theory and that Kantianism is a canonical example of a deontological ethical theory, but this is where the agreement ends. Often authors build into their definition of teleological or consequentialist theories a commitment to the maximization of value, ${ }^{6}$ but this is a mistake, for it neglects nonmaximizing versions of consequentialism. Even the familiar dictum that teleological/consequentialist theories make the good prior to the right and deontological theories make the right prior to the good is problematic. On the teleological/consequentialist side of things, this dictum rules out an increasingly popular form of consequentialism known as scalar consequentialism, which holds that there is no such thing as obligation

\footnotetext{
4 In particular, Dewey and Tufts $(1908,224)$ say that moral theories of the first sort are "frequently" called teleological.

5 Though, as Derek Parfit reminds me, with a different meaning from the one now used. (Thus 'consequentialism', 'teleology', and 'deontology' have all shifted in meaning over the years; see n. 2.)

6 See, for example, Frankena 1963, 13; Rawls 1971, 24; Scheffler 1988, 1; Brown 2011, 751; and Willenken $2012,545$.
} 
or rightness, just betterness. ${ }^{7}$ On the deontological side of things, the dictum rules out theories according to which sometimes an action's rightness or wrongness is entirely determined by the goodness of its consequences, but other times its rightness or wrongness is determined by other factors (such as the fact that it violates an absolute side-constraint). Moreover, the familiar dictum also neglects a recent strain of Kant interpretation that takes at face value Kant's claims about the unconditional goodness of a good will in the opening lines of the Groundwork and sees Kantian ethics as founded on a distinctive theory of value. ${ }^{8}$

This last observation points the way toward a more satisfactory definition of teleology. What is distinctive about the teleological perspective is not just its taking value to be fundamental, but moreover its attitude toward the nature of value and how we should respond to it. According to the teleologist, the proper response to value is to bring it about, and the proper response to disvalue is to stop it from being brought about: in short, for the teleologist all value is "to be promoted," and all disvalue is "to be prevented" (Pettit 1991, 230-33; Korsgaard 1993, 24; Pettit 1997, 125-30; Scanlon 1998, 79-80). This leads to two constraints on any given teleological theory. First, the fundamental bearers of value, whatever they are, must be the sort of thing that can be promoted or prevented. For example, a particular personcall him "Bob" - cannot, strictly speaking, be promoted or prevented (in the sense of these terms intended here: we're not talking about job promotions). So if a teleologist insists that Bob is a fundamental bearer of value, really what he or she means is that the state of affairs in which Bob exists has value and hence is to be promoted. For the teleologist, the true bearers of value are states of affairs, ${ }^{9}$ and any talk on the teleologist's part of concrete entities (be they persons or animals, things or events, mental states or personal relationships) having fundamental value is really shorthand for talk of the states of affairs in which those entities exist, occur, or happen having fundamental value. ${ }^{10}$ Second, the teleologist's conception of value commits him or her to the claim that all nonfundamental value is to be explained in terms of how well a

7 See Slote 1985, chap. 5; Howard-Snyder and Norcross 1993; and Norcross 2006a, 2006b.

8 Perhaps the clearest statement of this interpretation of Kant appears in Herman 1993, but it can also be found, to varying degrees, in the works of Marcia Baron, Paul Guyer, Thomas Hill, Jr., Christine Korsgaard, Onora O'Neill, and Allen Wood. For discussion, see Pippin 2001, 386-87; and Ridge 2009, 421.

9 Or entities that play roughly the same role as states of affairs, such as facts, or property instantiations, or (portions of) possible worlds.

10 Here I agree with Elizabeth Anderson (1993, 30-32) and T. M. Scanlon (1998, 80), and disagree with Douglas Portmore (2011, 129-31). 
bearer of nonfundamental value conduces toward the promotion of whatever those things are that have fundamental value; or in other words, nonfundamental value is explicable in terms of conduciveness toward fundamental value. These two constraints, together with the requirement that any facts that there might be about deontic notions such as obligation, permission, and rightness must obtain in virtue of facts about value, give us the heart of the teleological point of view.

With that in mind, we can define a teleological normative theory (whether in ethics or epistemology) as follows. Most teleological theories have three basic components: a theory of final value, a theory of overall value, and a deontic theory. However, a teleological theory need not have all three components; in particular, scalar versions of teleology lack a deontic theory. When all three theories are present, each successive theory crucially depends on the preceding one: the theory of overall value depends on the theory of final value, and the deontic theory depends on the theory of overall value.

A teleologist's theory of final value can be formulated in two different, but equivalent, ways, depending on whether it is formulated in terms of objects/ends or in terms of goals/aims. ${ }^{11}$ Formulated in terms of objects/ends, the theory specifies a certain set of states of affairs that have value or disvalue as ends in themselves. (It might also specify the degree to which they are valuable or disvaluable in this way.) Again, if we are speaking loosely, we can talk of concrete entities such as headaches or true beliefs having value or disvalue as ends, but really it is the state of affairs in which someone has a headache that has final disvalue, or the state of affairs in which someone has a true belief that has final value. Formulated in terms of goals/aims, the teleologist's theory of final value identifies a certain list of goals or aims that structure the norms under consideration. (It might also ascribe to each of these goals or aims a weight or strength.) Since this is a theory of final value, these must be ultimate goals or aims, not goals or aims that serve other, more basic goals or aims. Some of these goals will be positive goals: a goal of bringing about some state of affairs, or of making it the case that something happens. And some of these goals will be negative goals: a

11 The more traditional name for the teleologist's theory of final value is "a theory of intrinsic value." However, it is now widely recognized that the intrinsic vs. extrinsic value distinction is distinct from the final vs. instrumental value distinction (see Korsgaard 1983). Moreover, it is the latter distinction that is most crucial for this stage of the teleologist's project: there is no reason to restrict our range of ultimate ends to those that are valuable in virtue of their intrinsic properties. (For example, a theory of intrinsic value could not include true beliefs among the entities that are intrinsically valuable since other than in special cases such as a belief in the proposition $<\mathrm{I}$ have at least one belief $>$, most beliefs are true in virtue of their extrinsic properties; however, a theory of final value has no problem including true beliefs among the entities that have final value.) 
goal of avoiding some state of affairs, or of preventing something from happening. ${ }^{12}$ As should be apparent, these two ways of formulating a theory of final value are equivalent: the positive (or negative) goals in the latter formulation correspond to the ends with positive (or negative) value in the former. ${ }^{13}$

The teleologist's theory of overall value takes us from evaluations of the goodness or badness of certain states of affairs as ends in themselves to all-things-considered verdicts about the goodness or badness of any entities that conduce toward or promote those states of affairs. Because a teleologist may want to evaluatively rank many different sorts of entities - acts, beliefs, motives, rules, institutions, and so on-his or her theory of overall value might break up into several different subtheories corresponding to each of these evaluative focal points (to use Shelly Kagan [2000]'s helpful terminology). For each evaluative focal point, the teleologist's theory of overall value specifies a comparative ranking of every entity that falls within that evaluative focal point in terms of how well, all things considered, it conduces toward or promotes the various states of affairs that, according to the teleologist's theory of final value, have value or disvalue as ends in themselves. Different teleological theories will interpret what it takes for an entity $\mathrm{X}$ to promote or conduce toward a state of affairs $\mathrm{S}$ that has value or disvalue in different ways, including some or all of the following possibilities (and various combinations of these possibilities):

- $\mathrm{X}$ is a causal means to S: X's occurrence, happening, or existence (partially or entirely) causes it to be the case that $\mathrm{S}$ obtains.

- $\mathrm{X}$ instantiates $\mathrm{S}$ : for $\mathrm{X}$ to occur, happen, or exist just is for $\mathrm{S}$ to obtain.

- $\mathrm{X}$ is an "upward" constitutive means to $\mathrm{S}$ : X's occurrence, happening, or existence (partially or entirely) constitutes S's obtaining. ${ }^{14}$

- $\mathrm{X}$ is a "downward" constitutive means to S: X's occurrence, happening, or existence is (partially or

12 Negative goals/aims cannot be reduced to positive goals/aims: a negative goal of avoiding its being the case that $p$ is not equivalent to a positive goal of making it the case that not- $p$. (To say that I have a negative goal of avoiding work is not the same as saying that I have a positive goal of not-working.) Similarly, a disinclination to $\phi$ is not the same as an inclination to not- $\phi$, and disliking that $p$ is not the same as liking that not- $p$.

13 Strictly speaking, what I here call "a theory of final value" should be "a theory of pro tanto final value" that focuses on the specifically pro tanto goodness or badness of states of affairs as ends in themselves (that is, focuses on a given state of affair's goodness or badness as an end in a certain respect, not its goodness or badness as an end when all of the ways in which it might be good or bad as an end are weighed against each other). Since the arguments to follow depend more on the instrumental value vs. final value distinction than on the pro tanto value vs. all-things-considered value distinction, I have chosen to suppress this complication in my formulation of teleological theories, thereby avoiding the need to clutter my claims with "pro tanto" qualifiers.

14 An example: if my having read a certain book is valuable, then my having read the first page of that book might be a way of promoting that value, in virtue of its being an upward constitutive means to my having read the entire book. 
entirely) constituted by S's obtaining. ${ }^{15}$

Assigning an overall value to $\mathrm{X}$ involves (i) determining all the ways in which $\mathrm{X}$ stands in the relevant promoting relation to states of affairs of final value/disvalue, (ii) weighing all these various eventualities against each other, and (iii) comparing this net result to the net result for every other item that falls within X's evaluative focal point. Depending on how precisely the teleologist's theory of final value assigns weights or degrees of goodness, and on how precisely the teleologist specifies a weighing algorithm, the theory of overall value might result in a cardinal ordering (that is, a quantitative ordering that assigns specific numbers on some scale to the items being ranked), or it may merely result in an ordinal ordering (that is, an ordering that specifies only whether various items in the evaluative focal point have greater, lesser, or equal overall value in comparison to one another). ${ }^{16}$

The final element in a given teleological position is a deontic theory that assigns deontic properties such as being obligatory or permissible, being right or wrong, being justified or unjustified, on the basis of the theory of overall value. ${ }^{17}$ Again, since the teleologist may want to assign deontic properties to a variety of different entities - acts as well as beliefs, motives as well as character traits, rules as well as institutionshis or her deontic theory might split up into various subtheories corresponding to each of these deontic focal points. These subtheories can take two forms. If the deontic focal point is also an evaluative focal point, then the deontic subtheory will be a direct theory that assigns a deontic status to the items in the deontic focal point based on their ranking according to the portion of the teleologist's theory of overall value devoted to that evaluative focal point. There are various ways that this assignment could proceed: it could be a maximizing theory according to which item $\mathrm{X}$ in deontic focal point $\mathrm{D}$ is right if and only if there is no other item in D that has greater overall value than X; it could be a satisficing theory according to which item $\mathrm{X}$ in deontic focal point $\mathrm{D}$ is right if and only if its overall value is above some threshold; or the

\footnotetext{
15 An example: if my intending to perform some action is valuable, then my (intentionally) performing that action might be a way of promoting that value, in virtue of its being a downward constitutive means to my having the intention in question.

16 Note that if some of the teleologist's final values are incommensurable, incomparable, or vague, the resulting overall ordinal ordering might not be a total ordering (that is, there might be two items in the evaluative focal point such that the first is neither greater than, less than, nor equal in overall value to the second).

17 I assume here that being justified is a deontic property. If you disagree, replace the phrase 'deontic theory' with a term that encompasses your desired way of categorizing facts about justification.
} 
assignment could depend on the theory of overall value in a more complex manner. ${ }^{18}$ If the deontic focal point is not also an evaluative focal point, then the deontic subtheory for that focal point will be an indirect theory that assigns deontic properties to the members of that deontic focal point on the basis of a bridge principle linking that deontic focal point to another deontic focal point for which deontic statuses have already been assigned. The most familiar indirect deontic subtheory is the sort posited by ruleconsequentialism, in which right acts are defined in terms of right rules, and the rightness of rules is directly assessed in terms of how well (when properly internalized by a suitable portion of the population) the rules promote the good and don't promote the bad. ${ }^{19}$

My characterization of teleological normative theories has, of necessity, been quite abstract, but some examples will help bring our discussion down to earth. First, two examples of teleological theories in ethics:

maximizing hedonistic act-utilitarianism:

i. theory of final value:

Pleasurable experiences have value as ends.

Painful experiences have disvalue as ends.

Nothing else has value or disvalue as an end.

ii. theory of overall value (for evaluative focal point $\{$ acts $\}$ ):

S's $\phi$-ing at time $t$ has more overall value than S's $\psi$-ing at $t$ iff [the net balance of pleasure over pain that would be brought about if $\mathrm{S} \phi$ 's at $t]>$ [the net balance of pleasure over pain that would be brought about if S $\psi$ 's at $t]$.

iii. deontic theory (for deontic focal point $\{$ acts $\}$ and deontic property being right):

$\mathrm{S}$ 's $\phi$-ing at time $t$ is right iff no other act available to $\mathrm{S}$ at $t$ has more overall value.

satisficing hedonistic motive-utilitarianism: ${ }^{20}$

i. theory of final value:

Pleasurable experiences have value as ends.

Painful experiences have disvalue as ends.

Nothing else has value or disvalue as an end.

18 See, for example, Sider 1993 and Portmore 2008.

19 Different versions of rule-consequentialism vary, of course, in how they specify the states of affairs promoted by a given rule (or system of rules) and in how they link the deontic properties of rules to the deontic properties of acts. For some variations, see Pettit and Smith 2000, 130-31; and Kagan 2000, 137-38.

20 See Adams 1976, 478-79, although I have changed Adams's proposal in several ways (for instance, switching it from a maximizing to a satisficing theory) to make this example more analogous to an example from the epistemic realm that I discuss momentarily. 
ii. theory of overall value (for evaluative focal point \{motive-sets \}):

Motive-set $m$ has more overall value than motive-set $m^{\prime}$ iff $m$ tends (when possessed in a suitable range of circumstances) to lead to a greater balance of pleasure over pain in the world than $m^{\prime}$ does.

iii. deontic theory (for deontic focal point \{motive-sets\} and deontic property being right):

Motive-set $m$ is right iff [ $m$ 's overall value $\geq$ threshold T].

deontic theory (for deontic focal point \{acts\} and deontic property being right):

S's $\phi$-ing at time $t$ is right iff the motive-set that caused $\mathrm{S}$ to $\phi$ at $t$ is right.

Both of these normative theories are examples of ethical teleologies: they specify certain ultimate ends that we, as agents, should promote and then assign deontic properties on the basis of how well acts, motivesets, and the like conduce (whether directly or indirectly) toward those ends. In order to provide an example of an epistemic teleology, we need to focus on items that have distinctively epistemic value. In other words, we need to specify certain ultimate epistemic ends that we, as believers, should promote and then assign deontic properties on the basis of how well beliefs, cognitive processes, habits of thought, and the like conduce (whether directly or indirectly) toward those ends. Perhaps the most famous example of a teleological epistemic theory of this sort is process reliabilism:

\section{(simplified) process reliabilism:21}

i. theory of final value:

True beliefs have epistemic value as ends.

False beliefs have epistemic disvalue as ends.

Nothing else has epistemic value or disvalue as an end.

ii. theory of overall value (for evaluative focal point \{belief-forming processes $\}$ ):

Belief-forming process $b$ has more overall epistemic value than belief-forming process $b^{\prime}$ iff $b$ tends (when employed in a suitable range of circumstances) to yield a greater ratio of true to false beliefs than $b^{\prime}$ does.

iii. deontic theory (for deontic focal point \{belief-forming processes\} and deontic property being reliable):

Belief-forming process $b$ is reliable iff [ $b$ 's overall epistemic value $\geq$ threshold T].

deontic theory (for deontic focal point \{beliefs $\}$ and deontic property being justified):

$\mathrm{S}$ 's belief that $p$ at time $t$ is justified iff the belief-forming process that caused $\mathrm{S}$ to believe that $p$ at $t$ is reliable.

When observed side-by-side, the similarities between satisficing hedonistic motive-utilitarianism and process reliabilism should be quite striking. According to the former, an act is right iff it is caused by a

\footnotetext{
21 See Goldman 1992 [1979]. I add the qualification 'simplified' since this formulation of process reliabilism ignores the distinction between belief-dependent and belief-independent cognitive processes, which for our purposes we can disregard.
} 
motive-set that tends to do sufficiently well at bringing about one end (pleasurable experiences) and avoiding another end (painful experiences). According to the latter, a belief is justified iff it is caused by a process that tends to do sufficiently well at bringing about one end (true beliefs) and avoiding another end (false beliefs). These similarities are, I believe, no mere coincidence. Just as utilitarianism is the paradigm example of a teleological ethical theory, so too, I believe, reliabilism is the paradigm example of a teleological epistemic theory. This is not hard to see when we note that a more perspicuous - though far uglier — name for reliabilism is "truth-conducivism": process reliabilists hold that a belief is justified when it is caused by a sufficiently truth-conducive process, indicator reliabilists hold that a belief is justified when it is connected in some way to a sufficiently truth-conducive indicator, method reliabilists hold that a belief is justified when it is formed on the basis of a sufficiently truth-conducive method of belief formation, and so on. Thus if we take our sole ultimate epistemic end to be truth-in-belief (plus avoidance of falsity-in-belief), and if we make the distinctively teleological assumption that every other normative epistemic property is to be explained in terms of how well the thing bearing that property conduces toward the fulfillment of our ultimate epistemic ends, it is all too easy to slide into defending a version of reliabilism.

\section{The Pervasiveness of Teleology in Contemporary Epistemology}

I have just identified a widely discussed epistemic theory - namely reliabilism - that counts as teleological in structure. Once the basic distinction between teleological and nonteleological epistemic theories is pointed out, one naturally expects that, just as in the ethics literature where a wide variety of teleological theories are defended and a wide variety of nonteleological theories are defended, so too the epistemology literature should be populated by a wide variety of both teleological and nonteleological theories. But what one finds when one turns to the epistemology literature as it exists today is quite surprising, for a teleological approach to normative epistemology is overwhelmingly the dominant view.

Over the past three decades years, introductory epistemology courses have tended to have their own familiar narrative: namely, the ongoing struggle between internalist and externalist theories of justification. Internalists about justification hold that the facts that determine whether a belief of mine is justified must always be accessible to me upon reflection, or must always be facts about my own 
(nonfactive) mental states. Externalists about justification deny this: they hold that whether or not I am justified in believing something can, at least sometimes, be determined by facts that are beyond my ken, or by facts that are not entirely about my own (nonfactive) mental states. ${ }^{22}$ Because so much work in epistemology over the past few decades has centered on the conflict between internalists and externalists, structuring an introductory epistemology course around the clash between these two camps is difficult to resist. But what I, at least, find eye-opening is that when one considers the major figures in the debate between internalists and externalists about epistemic justification (thought by many to be the central debate in contemporary epistemology), almost all of them are committed teleologists about epistemic normativity.

Consider, first, externalists about epistemic justification. The canonical externalist theory is reliabilism, and the foremost defender of reliabilism is Alvin Goldman. Over the years, Goldman has been quite frank about his adherence to a teleological conception of epistemic normativity. In his first monograph devoted to defending reliabilism, Goldman $(1986,97)$ explicitly endorses a "consequentialist" rather than a "deontological" criterion for the rightness of a given system of justificational rules. In particular, he endorses a criterion whereby the consequences that matter are one's believing truths and not believing falsehoods (Goldman 1986, 98). In a more recent article, Goldman (2001, 32) writes that "true belief is the ultimate value in the epistemic sphere, and various belief-forming processes, faculties, or mechanisms are licensed as [epistemically] virtuous because they are conducive to true belief. Beliefs are justified when they are produced by these very truth-conducive processes." Thus, on his account, "The principal relation that epistemic virtues bear to the core epistemic value will be a teleological or consequentialist one. A process, trait, or action is an epistemic virtue to the extent that it tends to produce, generate, or promote (roughly) true belief" (Goldman 2001, 31). Goldman's commitment to a teleological/consequentialist normative framework could not be any more explicit, and many other externalists follow him in this regard.

22 I have characterized internalism and externalism disjunctively, in order to sidestep a current debate over whether internalism about epistemic justification is best formulated as what Earl Conee and Richard Feldman call "accessibilism" (where the internal is construed as that-to-which-I-have-some-special-sort-of-access) or as what they call "mentalism" (where the internal is construed as that-which-is-internal-to-my-mental-life). See Conee and Feldman 2004 [2001], 55. William Alston (1989 [1986]) makes a similar distinction between what he calls "access internalism" and "perspectival internalism." 
So let us turn to internalists about epistemic justification. Two of the foremost defenders of internalist theories over the years have been Laurence BonJour and Richard Foley. Although in his earlier work BonJour defended coherentism about a posteriori justification (BonJour 1976, 1978, 1985) and later defected, becoming a thorough-going foundationalist (BonJour 1999a, 1999b, 2003), all along BonJour has defended internalist versions of these epistemological positions and has vigorously argued against externalist approaches to epistemic norms (BonJour 1980, 2002). Given this, one might expect BonJour to be opposed to Goldman's teleological/consequentialist outlook on normative epistemology. But far from being opposed to such an outlook, BonJour is in fact one of its chief proponents. In a typical passage, BonJour $(1985,7-8)$ writes,

What makes us cognitive beings at all is our capacity for belief, and the goal of our distinctively cognitive endeavors is truth: we want our beliefs to correctly and accurately depict the world. . . The basic role of justification is that of a means to truth, a more directly attainable mediating link between our subjective starting point and our objective goal. ... If epistemic justification were not conducive to truth in this way, if finding epistemically justified beliefs did not substantially increase the likelihood of finding true ones, then epistemic justification would be irrelevant to our main cognitive goal and of dubious worth. ... Epistemic justification is therefore in the final analysis only an instrumental value, not an intrinsic one.

This essentially teleological way of thinking about the nature of epistemic justification is not an incidental part of BonJour's epistemological program. Not only does he affirm, time and time again, ${ }^{23}$ this idea that the features that render a belief epistemically justified must conduce toward its truth in a subjectively accessible manner, but moreover this idea serves as a crucial premise in many of BonJour's most famous arguments and objections, including (a) his old argument against foundationalism from his coherentist days (BonJour 1976, §2; 1978, §2; 1985, §2.3), (b) the objection to coherentism that most worried him when he was a coherentist (BonJour 1976, §4; 1985, §5.5), (c) his argument for including one of the more controversial elements in his version of coherentism, namely the "doxastic presumption" that a person's meta-representation of the contents of his or her entire system of beliefs is roughly correct (BonJour 1985, $\S 5.4 ; 2003, \S 3.1 .4)$, and (d) one of the objections to coherentism that eventually convinced him of its falsity (BonJour 1999a, 130; 2003, 58-59). Suffice to say, BonJour's commitment to epistemic teleology runs deep. ${ }^{24}$

\footnotetext{
23 See, among other places, BonJour 1976, 289; 1978, 5; 1980, 54; 1986, 94; 1998, 1; and 2010, 35.

24 Sometimes BonJour $(1985,8)$ glosses the relation between epistemic justification and the cognitive goal of truth in a way
} 
We find much the same thing with Richard Foley. Over the years Foley has defended what is widely regarded as the most thoroughly internalistic account of epistemic rationality yet developed. In fact, Foley's internalist conception of epistemic rationality has become so well known that it is usually referred to with his name attached to it: "Foley-rationality." To first approximation, a belief is Foleyrational iff it would survive a Cartesian meditation. To second approximation, a belief is Foley-rational iff it is the conclusion of an argument whose premises and inferences the subject would find uncontroversial if he or she were appropriately reflective and had unlimited time to reach a stable point of view. ${ }^{25}$ If this is all one knew about Foley's view, one might expect him to justify it with a nonteleological conception of epistemic normativity, especially given the Cartesian nature of his program. As it turns out, though, Foley is an unabashed teleologist. Both of Foley's books defending his account of epistemic rationality (Foley 1987 and 1993) open with chapters insisting that rationality in general is goal-oriented and that epistemic rationality in particular is structured around the fundamental goal of "now believing those propositions that are true and now not believing those propositions that are false" (Foley 1993, 19). Though an internalist, Foley is also a card-carrying teleologist.

Finally, let us consider a figure who is one of the foremost defenders of a hybrid epistemic theory that incorporates elements from both the externalist and internalist traditions, namely, William Alston. In his most recent book, Beyond "Fustification": Dimensions of Epistemic Evaluation, Alston resists the idea that there is only one sort of positive epistemic status - call it "justification"-that a belief might possess. Instead, he defends a pluralist theory according to which beliefs can have a variety of positive epistemic statuses - or "epistemic desiderata," as he calls them - some of which are more externalist in nature (for example, reliability), others of which are more internalist (for example, adequacy of grounds of belief). Thus it might seem that Alston's pluralist approach to normative epistemology would allow him to countenance epistemic desiderata not tied in a teleological/consequentialist way to the furthering of some goal or end, just as W. D. Ross's pluralist position in normative ethics includes both consequentialist and

that is not distinctively teleological, as amounting to little more than the requirement that "one accept all and only those beliefs which one has good reason to think are true." However, this more minimal claim is not equivalent to the requirement of subjectively accessible truth conduciveness. Moreover, it is the latter requirement that plays a role in (a) through (d).

25 For further approximations, see Foley 1987, 1993. 
nonconsequentialist elements. However, when Alston (2005, 29) turns to explaining why each of the desiderata he considers counts as an epistemic desideratum (rather than, say, a moral or prudential desideratum), he restricts himself to explanations that are decidedly teleological in character:

Epistemology consists of a critical reflection on human cognition. And the evaluative aspect of epistemology involves an attempt to identify ways in which the conduct and the products of our cognitive activities can be better or worse vis-à-vis the goals of cognition. And what are those goals? Along with many other epistemologists I suggest that the primary function of cognition in human life is to acquire true beliefs rather than false beliefs about matters that are of interest or importance to us.

Thus, for Alston, all epistemic desiderata are ultimately defined in terms of how well they help us further "the goals of cognition." A little later, Alston $(2005,32)$ makes it clear that he embraces a maximizing conception of these goals: our fundamental epistemic goal, he insists, is not just to acquire true rather than false beliefs about matters that are of interest or importance to us, but moreover to maximize our number of true beliefs about such matters and to minimize our number of false beliefs. This assumption of a teleological framework for epistemological theorizing is not a recent development in Alston's thought. In countless places in his seminal earlier work on the internalism/externalism debate, on doxastic voluntarism, on epistemic circularity, and on the epistemology of religious experience, Alston restatesand relies upon - his view that epistemic evaluation is always evaluation with regard to our basic cognitive goal of maximizing the number of one's true beliefs and minimizing the number of one's false beliefs in some body of belief. 26

Thus we see that one major externalist (Goldman), two major internalists (BonJour, Foley), and one major compromiser between externalism and internalism (Alston) are all committed teleologists. These examples have not been cherry-picked to suit my purposes: the number of epistemologists from across the externalist-internalist spectrum who adhere to a basically teleological perspective on epistemic normativity is astounding. ${ }^{27}$ There are, of course, a few exceptions. ${ }^{28}$ But overwhelmingly, much of the

26 See, among other places, Alston 1989 [1976], 305; 1989 [1985], 83; 1989 [1988a], 116; 1989 [1988b], 231-32; 1989, 3; 1991, 72; and 1993, 3-4. (In most of these earlier works, however, Alston does not add the proviso that the beliefs in question must be ones "of interest or importance to us.") Note that not only does Alston restate his commitment to teleology in all of these places, but moreover that commitment almost always serves as a premise in the arguments that follow. To give but one example: during a crucial point in his well-known argument against what he calls "the deontological conception of epistemic justification," Alston (1989 [1988a], 143-52) argues that certain beliefs cannot be justified since they were not formed in a truth-conducive way (nor in a way the subject is justified in believing to be truth conducive).

27 Other adherents to a teleological approach to epistemic normativity include, but are not limited to, Ralph Baergen (1995), Anthony Booth (2006, 2008), Berit Brogaard (2009), Marian David (2001, 2005), Brian Ellis (1988), Richard Feldman (1988, 2002), Hartry Field (1982, 1998, 2000), Peter J. Graham (2011), John Greco (1993, 1999), Stephen Grimm (2008, 2009), Richard 
recent debate between internalists and externalists in epistemology can be seen as an in-house dispute among teleologists.

During the latter portion of the twentieth century, this basic assumption of a teleological approach to normative epistemology was largely under the surface. But more recently, it has become its own area of research. There is now an active debate over what "our epistemic goals" are: whether they are just the attainment of true beliefs and the avoidance of false beliefs, as some contend, ${ }^{29}$ or whether this list needs to be revised or expanded to include other items. ${ }^{30}$ And in the past decade there have been conferences, workshops, and blogs devoted exclusively to the topics of "epistemic value" and "epistemic goodness." One author has even gone so far as to proclaim that we are undergoing a "value turn in epistemology" as more and more epistemologists recognize the importance of what he calls "value-driven epistemology": an approach to normative epistemology that proceeds by first specifying our basic epistemic goals or values and then connecting all other normative notions in epistemology to the furtherance of these goals or the promotion of these values (Riggs 2008b).

Lost in the shuffle during this ferment of excitement about epistemic goals, epistemic value, valuedriven epistemology, and the like has been the possibility that we might not have distinctively epistemic goals, that epistemic norms might not be ultimately grounded in facts about epistemic value, and that the teleological/consequentialist commitments of value-driven epistemology might not be correct. My favorite example of the overlooking of such a possibility occurs in the recent volume Contemporary Debates in

Hall and Charles Johnson (1998), Allan Hazlett (2006, n.d.), Hilary Kornblith (1985, 1993, 2002), Jonathan Kvanvig (2003, 2005, 2011), Keith Lehrer (1977, 1981, 1988), Jarrett Leplin (2007, 2009), Michael Lynch (2004, 2009a, 2009b), Stephen Maitzen (1995), Nenad Miscevic (2007), James Montmarquet (1987, 1993, 2008), Philip Percival (2002), Alvin Plantinga (1988, 1993a, 1993b), Steven Reynolds (2002), Wayne Riggs (2003, 2008a, 2008b), Darrell Rowbottom (2008), Frederick Schmitt (1992, 2000), Tomoji Shogenji (2012a, 2012b), Asbjørn Steglich-Petersen (2009, 2011, n.d.), Hamid Vahid (2006, 2010, 2011), Ralph Wedgwood (2002, 2008), Jonathan Weinberg (2007), Dennis Whitcomb (2007, 2011), and at least certain time-slices of Paul Moser (1985) and Ernest Sosa (1991).

One issue I do not take a stand on in the current essay is whether defenders of sensitivity/safety conditions on knowledge/justification should be regarded as epistemic teleologists, in my sense. Settling whether satisfying one of these conditions counts as a way of conducing toward or promoting epistemic value would take us too far afield, and extending the arguments to come so that they encompass sensitivity and safety views would make an already complicated argument hopelessly byzantine. I hope to address the topic of whether sensitivity and safety views are susceptible to variants of the arguments found in this essay in future work.

28 For example, Richard Fumerton (2001, 54-56; 2002, 208-9; 2006, 34-35) argues against construing claims about what we ought to believe as claims about the efficacy of achieving certain goals or ends. Note, also, that quite a few epistemologists are noncommittal in their work about the truth or falsity of a teleological approach to epistemology.

29 Most prominently, Marian David (2001, 2005).

30 As Stephen Maitzen (1995), Michael DePaul (2001), Wayne Riggs (2002), Jonathan Kvanvig (2005), Berit Brogaard (2009), and Stephen Grimm (2009) have all argued. 
Epistemology edited by Matthias Steup and Ernest Sosa. In it, a number of classic epistemological questions such as "Can skepticism be refuted?" and "Is there a priori knowledge?" are debated by a group of prominent epistemologists. For each question, one author defends the "yes" answer to the question, and another author defends the "no" answer. One of these questions is "Is truth the primary epistemic goal?," with Marian David (2005) arguing that it is and Jonathan Kvanvig (2005) arguing that there are other primary epistemic goals beyond truth. But the question "Is truth the primary epistemic goal?" of course presupposes that we have epistemic goals, some of which are more primary than others, and neither David nor Kvanvig disputes this. Somehow during the past few decades a teleological approach to epistemic normativity has become so uncontroversial that it is now not even up for debate.

\section{Ethical Trade-Offs and the Separateness of Persons}

My aim in this essay, as I have already made clear, is to argue against this growing trend of assuming that epistemic theories must be teleological in structure. I think that teleology/consequentialism in normative ethics has its attractions, but these attractions do not all translate well when applied to normative epistemology. It is one thing to have a goal-oriented approach to what we should do - to ground facts about should-be-done-ness in facts about what conduces toward the promotion of value. But a goaloriented approach to what we should believe? Such a conception of epistemology, I believe, yields a variety of implausible results. Facts about what we should believe do not, I believe, obtain in virtue of facts about what conduces toward the promotion of items that possess a distinctively epistemic sort of value. Moreover, if they did, then teleological theories in epistemology would look a lot more like teleological theories in ethics than any epistemologist is - or should be - willing to accept. Or so, at least, I will argue. But first I need to quickly review some familiar features of teleological/consequentialist theories in ethics, since they will prove important in the argument to come.

One of the greatest virtues, as well as one of the greatest vices, of the teleological/consequentialist approach to ethics is its countenancing of trade-offs in its determination of what we should do. Most teleological ethical theories have no problem explaining why we should sometimes sacrifice one person's life in order to save the lives of five people, or why we should sometimes allow a certain tragedy to befall 
several people in order to prevent an even greater tragedy from befalling a much larger group of people. I call this feature of teleological ethical theories a virtue because, in a large number of cases, allowing or prescribing such a trade-off strikes most of us as the correct result, and teleological theories can easily explain why this might be so. Most nonteleological ethical theories, on the other hand, have a more difficult time accommodating trade-offs. This leads to what I consider to be one of the deepest challenges for nonteleological/nonconsequentialist theories in ethics: how to include an aggregative element in one's theory, so as to allow for trade-offs in some cases, without that aggregative element overrunning one's theory and turning it into a version of teleology/consequentialism. How does one make the numbers sometimes count, and sometimes carry the day, without making them always count, and always carry the day? This is a problem that many who adopt a nonteleological approach to normative ethics must grapple with. ${ }^{31}$

However, this countenancing of trade-offs is also, notoriously, one of ethical teleology's greatest vices. The ease with which teleological ethical theories allow-and usually mandate - trade-offs is what gives rise to many of the most famous intuitive counterexamples to such theories: think, here, of cases in which a doctor has the ability to trade the life of a healthy individual attending a routine check-up for the lives of five people each in need of a new organ (Thomson 1976, 206), or in which a sheriff has the opportunity to trade the framing of an innocent man for the health and happiness of those who would otherwise be harmed by an angry mob (McCloskey 1957, 468-69), or in which a botanist has the chance to trade the murder of one South American villager by his own hand for the murder of twenty villagers by the hand of a soldier from a military junta (Williams 1973b, 98-99). When the trade-offs in question are interpersonal - that is, when the trade-offs involve harming or hurting one person in order to benefit or advantage a second person - then the common refrain is that, in permitting or requiring such trade-offs, teleological ethical theories "ignore the separateness of persons." 32 The idea here is that teleological theories such as act-utilitarianism do not treat intrapersonal trade-offs - trade-offs that involve harming or

\footnotetext{
31 Consider, for example, T. M. Scanlon's (1998, 229-41) attempt to incorporate a limited aggregative element in his contractualism in What We Owe to Each Other, which Scanlon $(2002,354)$ later singles out as the part of that book with which he is the least satisfied.

32 A worry most famously voiced by John Rawls (1963, 124; 1971, 26-27) but also endorsed, in different forms, by David Gauthier (1962, 126), Thomas Nagel (1970, 134), Robert Nozick (1974, 32-33), and a host of others.
} 
hurting a given person in one way in order to benefit or advantage that same person in another way - as fundamentally any different from interpersonal trade-offs when determining what an agent should do, but whereas intrapersonal trade-offs are morally defensible when the benefit to the one person outweighs the harm, interpersonal trade-offs are not morally defensible in the same way, or at least not always morally defensible in the same way.

I take no stand here on whether those teleological ethical theories that ignore the separateness of persons are making a moral mistake in doing so. My point, rather, is that it is ethical teleology's proclivity for trade-offs that opens some (but not all) versions of it to the charge of ignoring people's separateness. Ethical teleologists tend to respond to this charge in one of two ways: either they attempt to reformulate their theory so that it does not deem the problematic sorts of interpersonal trade-offs to be morally permissible, or they argue that - common sense be damned - the allegedly untenable interpersonal tradeoffs allowed by their theory are in fact morally defensible.

Why, though, are teleological ethical theories so amenable to trade-offs, whether inter- or intrapersonal? It is, I believe, because of a deep structural feature possessed by all teleological ethical theories, together with two more specific features possessed by many (but not all) such theories. The deep structural feature is this: all teleological ethical theories build a theory of overall value out of a theory of final value. The first more specific feature is this: most teleologists defend a theory of final value that allows for the possibility of conflicts or competition between the values making up that theory. Put these two features together, and we have a problem: in cases of conflict or competition between final values, how do we determine overall value? For example, what do we do if an item in a given evaluative focal point conduces toward a state of affairs that is good as an end but also conduces toward a different state of affairs that is bad as an end (a case of conflict), or if one item in an evaluative focal point promotes a state of affairs that is good as an end, and another item in the same evaluative focal point promotes a different state of affairs that is also good as an end (a case of competition)? In order to reach a fixed verdict about overall value, it seems that the teleologist needs some way of trading off these values against one another, some way of (to use another common metaphor) weighing the final goodness/badness of one eventuality against the final goodness/badness of another. The most common approach among teleologists for 
settling these matters is through aggregation: all of the values and disvalues promoted by a given item are somehow aggregated together (either additively or otherwise), and the conglomerated sum is compared to the conglomerated sum that we get for every other item in the item's evaluative focal point. This is the second more specific feature that explains why many teleological ethical theories are so amenable to trade-offs: when conflicts and competition among final values are settled through aggregation, the allowing or prescribing of trade-offs becomes rampant.

I have just identified one deep structural feature possessed by all teleological ethical theories plus two more specific features possessed by many such theories that together, I claim, explain why ethical teleology so often countenances a wide variety of trade-offs. But now here's the crucial point: many, if not all, teleological epistemic theories share these three features. They, too, build a theory of overall value out of a theory of final value. They, too, allow for conflicts and competition between items of final value. And they, too, settle these conflicts and competition through aggregation. So we should expect most teleological epistemic theories to countenance a wide variety of trade-offs. But that's precisely where they run into trouble.

\section{Epistemic Trade-Offs and the Separateness of Propositions}

The time has finally come to argue against the teleological approach to normative epistemology. I aim my argument to be as general as possible, but it will help to start by constructing an argument against a slightly narrower target and then generalizing later.

So let us begin by considering a version of epistemic teleology that holds the following theory of final epistemic value: true beliefs have epistemic value as ends, false beliefs have epistemic disvalue as ends, and nothing else has epistemic value or disvalue as an end. Or to formulate things in terms of goals instead of ends: according to this theory of final epistemic value, our only ultimate epistemic goals are (i) the accumulation of true beliefs and (ii) the avoidance of false beliefs. Adapting some terminology of Goldman's (Goldman 1999, 5; 2001, 31), let us refer to this theory of final epistemic value as "veritism," and let us call teleological epistemic theories that include veritism as their first component "veritistic."

Veritism is, in many ways, the default theory of final value for epistemic teleologists. Indeed, in 
the quotations I provided in §3, Goldman, BonJour, Foley, and Alston all endorse versions of veritism. However, the attentive reader will note that although Foley and Alston refer to both the positive goal of acquiring true beliefs and the negative goal of avoiding false beliefs, Goldman and BonJour only mention the first of these. Why, then, include two goals rather than one?

That we need two separate goals here is a point usually attributed to William James $(1897,17-$ 19). If we include only a positive goal of accumulating true beliefs, that would encourage epistemic recklessness. In the limit, one could trivially satisfy this goal by believing every proposition; of course, doing so would ensure that one believes a large number of falsehoods since for every proposition one believes, one will also believe its negation, but if there is no negative goal of avoiding false belief, then no epistemic harm is done in believing a few extra falsehoods. On the other hand, if we include in our theory of final value a negative goal of avoiding false beliefs without a corresponding positive goal of acquiring true beliefs, that would encourage undue epistemic caution. In the limit, one could trivially satisfy the negative goal by not believing anything, or - if that is not possible - by believing as little as one can. In James's (1897, 18) memorable words, someone who advocates the avoidance of error without also stressing the importance of believing the truth "merely shows his own preponderant private horror of becoming a dupe." For these Jamesian reasons, it is widely (though not universally: see Piller 2009) accepted that we need both of these goals to capture what people are after when they talk of "the search for truth" or say things like "I want the truth." For convenience, however, many authors who endorse these twin goals group them together under a single heading which they call "the truth-goal," 33 and we can assume that Goldman and BonJour are following this practice in the passages quoted earlier.

Three points of clarification before I precede:

1. Veritism is logically distinct from the view, first proposed by Bernard Williams (1973a [1970], 136-37) but since defended by others (including David Velleman [2000a], Ralph Wedgwood [2002], Pamela Hieronymi [2006], and Asbjørn Steglich-Petersen [2009]), that it is a constitutive feature of beliefs that they "aim at the truth." Appealing to such a view about the nature of belief

33 See, for instance, David 2001, 152-53. 
is one natural way of motivating veritism. However, it is not the only way. Compare: one need not hold that actions constitutively aim toward pleasure and away from pain in order to hold the hedonistic theory that pleasure and the avoidance of pain are our ultimate practical ends. (Hedonistic act-utilitarians are not logically committed to the thesis that action has a constitutive aim.) And, conversely, those who hold that action has a constitutive aim are not required to be consequentialists; indeed, so-called constitutivists about practical reason rarely are consequentialists (see Korsgaard 2008, 2009; Velleman 2000b, 2009). So, too, in the epistemic case: veritism neither entails, nor is entailed by, the view that it is a constitutive feature of beliefs that they "aim at the truth."

2. Although it is common for defenders of veritism to speak of the acquisition of true beliefs and the avoidance of false beliefs as being "our" fundamental epistemic goals, epistemic teleology-as I understand it here - is not committed to the view that every agent as a matter of fact possesses the goals featured in its theory of final epistemic value. Thus it is no objection to veritism that some of us don't desire to believe the truth about every proposition. Again, a comparison with teleological ethical theories that include a hedonistic theory of final value is instructive: it is no objection to hedonistic act-utilitarianism that there are some pleasurable experiences that some of us don't desire to bring about, or that there are some painful experiences that some of us are not averse to bringing about. Rather, what the hedonistic act-utilitarian is committed to is the following: all ethical evaluation is ultimately evaluation with regard to the twin goals of promoting pleasurable experiences and preventing painful experiences. Similarly, an epistemic teleologist who adheres to veritism is committed to the following: all epistemic evaluation is ultimately evaluation with regard to the twin goals of acquiring true beliefs and avoiding false beliefs, whether or not the agent being evaluated possesses these goals. ${ }^{34}$

34 Thus the target of my argument in this essay is importantly different from the target of Kelly 2003. Kelly is criticizing a view he calls "the instrumental conception of epistemic rationality," but as Kelly understands that view, it holds that epistemic rationality is instrumental rationality in the service of epistemic goals that we actually possess, and Kelly's argument crucially turns on denying that we always have the epistemic goals in question. 
3. I have been speaking here as if veritism countenances just two ultimate epistemic goals, but strictly speaking that is not accurate. Rather, what we have is a vast plethora of positive ultimate epistemic ends (to believe $\langle p\rangle$ if $\langle p\rangle$ is true, to believe $\langle q\rangle$ if $\langle q\rangle$ is true, to believe $\langle r\rangle$ if $\langle r\rangle$ is true, and so on, for every proposition), and a vast plethora of negative ultimate epistemic ends (to not believe $\langle p\rangle$ if $\langle p\rangle$ is false, to not believe $\langle q\rangle$ if $\langle q\rangle$ is false, to not believe $\langle r\rangle$ if $\langle r\rangle$ is false, and so on, for every proposition). ${ }^{35}$ Some writers object to this way of conceiving of the commitments of veritism on the grounds that it implausibly ascribes to agents an infinite number of goals (David 2001, 165), but in light of the previous point, we can see that this objection is neither here nor there: to say that there are an infinite number of ultimate goals structuring epistemic norms is not the same as saying that every agent who is subject to those norms must possess an infinite number of goals. ${ }^{36}$

This last comment points the way to the central problem with veritistic teleological theories. I said earlier that we should expect most epistemic teleological theories to permit or prescribe trade-offs between their fundamental aims. That veritistic teleological theories need to allow for trade-offs between the positive goal of believing a proposition if it is true and the negative goal of not believing that same proposition if it is false is a familiar point in the literature on epistemic goals. ${ }^{37}$ But what has not, in my opinion, been sufficiently appreciated is the degree to which veritistic theories also need to allow for tradeoffs between our epistemic goals with respect to different propositions: they must balance the positive goal of believing one proposition if it is true against the positive and negative goals associated with believing all other propositions, and they must balance the negative goal of not believing one proposition if it is false against the positive and negative goals associated with believing all other propositions. But such trade-offs, I put forward, are beyond the pale.

To see why, consider the following case, which is originally due to Roderick Firth (1998 [1978],

35 Here and throughout, I follow the convention of using " $<p>$ " as a name for the proposition that $p$.

36 Moreover, it is not clear to me what would be so objectionable about ascribing an infinite number of goals to an ordinary agent, especially if one holds a broadly dispositionalist account of belief and desire (such as functionalism). After all, most finite objects possess an infinite number of dispositions. So why, then, can't those who hold a dispositionalist account of belief and desire say that finite agents are able to possess an infinite number of beliefs and desires, and hence an infinite number of goals?

37 For example, Wayne Riggs (2003, 2008a) makes much of this point. 
326; 1998 [1981], 261), although the version of it that I am using I owe to Richard Fumerton (2001, 55). ${ }^{38}$ Suppose I am a scientist seeking to get a grant from a religious organization. Suppose, also, that I am an atheist: I have thought long and hard about whether God exists and have eventually come to the conclusion that He does not. However, I realize that my only chance of receiving funding from the organization is to believe in the existence of God: they only give grants to believers, and I know I am such a bad liar that I won't be able to convince the organization's review board that I believe God exists unless I genuinely do. Finally, I know that, were I to receive the grant, I would use it to further my research, which would allow me to form a large number of new true beliefs and to revise a large number of previously held false beliefs about a variety of matters of great intellectual significance. Given these circumstances, should I form a belief that God exists? Would such a belief be epistemically rational, or reasonable, or justified?

I think most of us will agree that were I to form a belief in God's existence on this basis, I would not be epistemically rational or reasonable or justified in doing so. And this is despite the fact that, in so believing, I would be greatly furthering what veritism deems to be my ultimate epistemic ends, namely, the accumulation of true beliefs and the avoidance of false beliefs. From veritism's perspective, my coming to believe in God's existence would be a sacrifice for the greater (epistemic) good: I would be trading off the pursuit of one thing of final epistemic value (true belief and the avoidance of false belief with regard to the proposition $<$ God exists $>$ ) in order to greatly facilitate my pursuit of a variety of other things of final epistemic value (true belief and the avoidance of false belief with regard to the propositions that make up the subject matter of my scientific research). It is difficult to see how veritism - at least as we have defined it so far - can avoid saying that such a trade-off would maximize overall epistemic value. And this would seem to be so regardless of whether the veritist's theory of overall epistemic value is applied to the evaluative focal point $\{$ beliefs $\}$ or to other evaluative focal points such as \{belief-forming processes\} or \{methods of belief formation\}: a belief-forming process that yields a belief in God's existence in the given

\footnotetext{
38 Similar uses of similar cases can be found in Blumenfeld and Blumenfeld 1978, 253; Booth 2006, 137-38; Christensen 2004, 4-5 and 173; Conee 2004 [1992], 249-51 and 256-57; Feldman 1988, 249-50; Feldman 2008, 346; Foley 1987, 8; Foley 1993, 20; and Jenkins 2007, 37. However, all of these authors use these examples only to argue against extremely crude forms of epistemic teleology. One of the central tasks of the current essay is to show that Firth-style examples are a problem even for very complicated and sophisticated teleological epistemic theories.
} 
circumstance would, surely, tend to promote veritism's ultimate epistemic ends better than one that doesn't, and similarly for a method of belief formation that results in such a belief in such situations. ${ }^{39}$ So regardless of how we fill in the veritist's theory of overall value and deontic theory in order to form a complete teleological epistemic theory, it appears that the veritist is committed to the highly implausible claim that my coming to believe in God's existence in order to get the grant is epistemically rational/reasonable/justified.

My aim here is not to argue by counterexample. Rather, I want to use this example to illustrate a more general point that I think is undoubtedly correct, even if, because of certain idiosyncratic details, the current example is not the best way to illustrate it. The more general point is this: when determining the epistemic status of a belief in a given proposition, it is epistemically irrelevant whether or not that belief conduces (either directly or indirectly) toward the promotion of true belief and the avoidance of false belief in other propositions beyond the one in question. Veritistic epistemic teleology, in flouting this fact, ignores what we might call "the epistemic separateness of propositions," just as many forms of consequentialism ignore "the ethical separateness of persons." ${ }^{40}$ Moreover, whereas in the ethical case there is some room for arguing that it is not a normative mistake to ignore the separateness of persons, since all of us think that at least some trade-offs that cross the barrier between persons are morally acceptable, in the epistemic case there is no wiggle room: the epistemic separateness of propositions is nonnegotiable. When it comes to the evaluation of individual beliefs, it is never epistemically defensible to sacrifice the furtherance of our epistemic aims with regard to one proposition in order to benefit our epistemic aims with regard to other propositions (even if we grant to the teleologist that there are such things as distinctively epistemic aims and that all epistemic appraisal should be explicated in terms of how well the objects of appraisal conduce toward the furtherance of those aims). ${ }^{41}$

\footnotetext{
39 To secure these results, we may need to increase the number of true beliefs that I would acquire were I to receive the grant, or increase the frequency in the actual world of situations like the one I face (or both). Doing so makes the example more fanciful, but does not change its basic structure.

40 More precisely, I should speak here of "the epistemic separateness of propositions-at-a-time" since it is also epistemically irrelevant whether or not a belief in $\langle p\rangle$ at a given time conduces toward the promotion of true belief and the avoidance of false belief with regard to that same proposition at later times. To avoid cumbersome locutions, I will often say "proposition" in what follows when I really mean "proposition-at-a-time."
}

41 Notice that my objection here applies just as well to a version of veritism according to which, rather than all true beliefs 
Two ways of responding to this argument immediately spring to mind. The first response is to hold onto veritism as a theory of final epistemic value but to restrict the teleologist's theory of overall epistemic value so as not to include causal means among the ways in which an item in a given evaluative focal point can conduce toward or promote items of final epistemic value. For example, maybe only constitutive means count as ways of conducing toward the furtherance of our veritistic aims of believing truths and not believing falsehoods. This restriction would, of course, immediately block any untoward results for the teleologist in the case of the grant-seeking scientist since in that example the scientist's belief in the existence of God is merely a causal means to the acquisition of various true beliefs and the avoidance of various false beliefs sometime in the future. But the question to ask is: why should we restrict what counts as conducing toward or promoting value in this way? What is the motivation, for the veritistic epistemic teleologist, in making this move (other than to avoid a potential problem)? On the epistemic teleologist's basic picture, certain items (such as true beliefs) have nonderivative epistemic value, and certain other items have derivative epistemic value insofar as they conduce toward the items of that first sort. What is the rationale for restricting this conducing relation so that it doesn't cover causal means? Nothing in the epistemic teleologist's basic picture suggests an answer to this question. ${ }^{42}$

A second way of responding to the argument I have presented is to take a hint from Foley. You will recall that Foley $(1993,19)$ specifies the content of our most basic epistemic goal as "now believing those propositions that are true and now not believing those propositions that are false" (emphasis mine). So maybe what the teleologist should do is reformulate his or her theory of final epistemic value so that the goals in question - and, correspondingly, the items of value - are time indexed in this manner. Let us call this new version of veritism "time-relative veritism." (Thus the original version of veritism is more

having epistemic value as ends, it is only true beliefs in propositions of interest or importance to us that have epistemic value as ends. A number of authors, including Alston (2005, 32) and Goldman (1999, 88-89; 2001, 38-39), restrict veritism in this way to avoid the worry that trivial truths - such as the phone number of the 323rd person listed in a now-defunct phonebook for Wichita, Kansas - do not seem to be the sorts of things that, from a purely epistemic point of view, we should seek to believe for their own sake. However, conflicts can occur between our veritistic aims with regard to different propositions even when all of the propositions in question are interesting or important, as the example of the grant-seeking scientist shows, so restricting veritism in this way does not help avoid the charge that veritistic teleological theories ignore the separateness of propositions.

42 Moreover, it is worth pointing out that process reliabilism - which, as we saw, is perhaps the most prominent example of a teleological epistemic theory - does allow causal means to be a way of conducing toward or promoting final epistemic value. (Most forms of process reliabilism restrict these causal means to cases of proximate causation, in which a belief-forming process directly causes the formation of a true or false belief without the help of any causal intermediaries, but this is still to allow that causation can be a way of promoting epistemic value. I discuss the restriction to proximate causal means below.) 
accurately described as "time-neutral veritism.") Formulated in terms of objects/ends, time-relative veritism holds that (i) for every currently true proposition $\langle p\rangle$, a state of affairs in which the agent now believes that $p$ now has epistemic value as an end; (ii) for every currently false proposition $\langle q\rangle$, a state of affairs in which the agent now believes that $q$ now has epistemic disvalue as an end; and (iii) nothing else now has epistemic value or disvalue as an end. Formulated in terms of goals/aims, time-relative veritism holds that, at a given time, our only positive ultimate epistemic aims are, for every proposition, to now believe that proposition if it is now true, and our only negative ultimate epistemic aims are, for every proposition, to now not believe that proposition if it is now false. Once veritism has been reformulated in this way, cases like the grant-seeking scientist are no longer an obvious embarrassment for the veritistic teleologist: that the scientist will arrive at many true beliefs and have fewer false beliefs in the future if he or she believes that God exists is, from the perspective of time-relative veritism, epistemically irrelevant. All that matters epistemically, according to the time-relative veritist, is whether or not the scientist's belief that God exists promotes true belief and the avoidance of false belief at the time at which it is held. ${ }^{43}$

This move on the veritistic teleologist's part is structurally identical to a similar move employed by many ethical teleologists who seek to incorporate, within their teleological theory, the verdict that it is impermissible to murder someone in order to prevent five murders from being committed. At first it might seem puzzling how a teleological ethical theory could yield such a result. If one murder is bad, wouldn't five murders be worse, and thus isn't an action that involves committing one murder in order to prevent five murders better overall - and hence more choiceworthy - than an action that involves abstaining from that one murder, thereby allowing the five to occur? (For expository purposes, I assume here that the teleological theory in question is a version of act-consequentialism; the point generalizes.) The first move that the teleologist can make to evade this result is to include both agent-relative and agent-neutral values in his or her theory of final value and then to insist that murders have an especially strong agent-relative disvalue: from my perspective as an agent confronted with a decision about what to do, the state of affairs in which $I$ murder someone has, according to this sort of teleologist, much more disvalue than the state of

\footnotetext{
43 Though this raises the question: is the time-relative veritist who does not also restrict the conducing relation to preclude causal means committed to the result that, even if the scientist's belief in the existence of God is initially epistemically unjustified, that belief becomes justified once the scientist comes to hold the other beliefs that he or she forms as a result of the grant?
} 
affairs in which a murder occurs. If this move is defensible, ${ }^{44}$ then it allows the teleologist to handle cases in which I can choose to murder someone in order to stop five other murders from being committed by a person (or group of people) other than myself since the murder I would commit has much more agentrelative plus agent-neutral disvalue than the five other murders I would prevent. However, the move to agent-relative value does not handle cases in which I can choose to murder someone in order to stop myself from murdering five other people sometime in the future (Kamm 1993, 95; 1996, 242). This kind of case leads teleologists who want to countenance bans on such trade-offs to make a second move, namely to allow both time-relative and time-neutral values in their theory of final value and then to insist that murders have an especially strong time-relative disvalue: from my perspective now as an agent, the state of affairs in which I now murder someone has much more disvalue than a state of affairs in which I murder someone at a different time. Or so, at least, some ethical teleologists argue.

Thus the transition from time-neutral to time-relative veritism is an instance of a familiar ploy in the teleologist's bag of tricks. ${ }^{45}$ Again, though, we should ask: what is the motivation in making this move? Why is it that current true beliefs have epistemic value as ends, but - mysteriously - future true beliefs do not? Like the move of restricting the conducing relation so as to preclude causal means, this move of timerelativizing our ultimate epistemic ends has the feel of an ad hoc maneuver invoked purely to get around a potential objection. Moreover, there is an additional problem with the transition to a time-relative conception of epistemic value: deliberation takes time. When I deliberate about whether to believe that $p$, my aim seems to be to eventually come to the right belief on the matter, even if I realize that-because the question is particularly difficult, or my evidence frustratingly equivocal, or my mind currently addled - it might take me quite a while to reach a final verdict. But from the perspective of time-relative veritism, this attitude is misguided: if my ultimate epistemic goal vis-à-vis the proposition $\langle p\rangle$ is to now believe it if it is true and to now not believe it if it is false, then it seems that the goal of my deliberations should be to settle the matter now, not (say) ten minutes from now after I have brought my ponderings to a close. But this

\footnotetext{
44 For some doubts, see Ridge 2009, 425-26, following on Kamm 1993.

45 Moreover, the other transition mentioned earlier, namely, from an agent-neutral to an agent-relative conception of value, is one that is already implicitly made by most veritists. Most veritists take epistemic value to be agent-relative: what matters to the epistemic assessment of my belief-forming practices, according to them, is whether those practices promote my holding true beliefs and $m y$ avoiding false beliefs, not whether they promote anyone's holding true beliefs and anyone's avoiding false beliefs.
} 
strikes me as an extremely odd, perhaps even incoherent, attitude to take toward deliberation, which of necessity is a continuous process that takes place over time across a series of distinct nows.

I have just mentioned two strategies for replying to my objection that veritistic teleological theories illicitly ignore the separateness of propositions: the first involves excluding causal means from being a way in which epistemic value can be promoted, the second involves moving from a time-neutral to a time-relative conception of our ultimate epistemic aims. In both cases I have expressed some reservations about these responses: neither is well motivated, and the second is in tension with the fact that theoretical deliberation takes place over time. But those are not the most pressing problem with these two responses. No, the most pressing problem is that although these responses allow the teleologist to avoid some cases involving illicit cross-propositional trade-offs, they do not allow him or her to avoid all such cases.

To see why, consider this. Although theoretical reasoning and deliberation often seems to be concerned with a single proposition - "Is the library open today?," "Will it rain this afternoon?," "Did she do that on purpose?" - as reasoners we rarely reach a verdict about a single proposition at a time, even if only one proposition is the main focus of our attention. Similarly, when forming beliefs in ways other than through explicit reasoning, we rarely - if ever - acquire beliefs one at a time; rather, we tend to acquire batteries of interconnected beliefs about a given subject matter. But if one of these batteries of beliefs contains an inevitable false belief but also many true beliefs, then accepting that battery of beliefs could be a constitutive means of sacrificing our veritistic aims with regard to one proposition in order to at the same time further our veritistic aims with regard to a large number of other propositions. So even veritistic epistemic teleologists who restrict themselves to constitutive means or to a time-relative theory of final epistemic value must concede that there can be cases in which it is epistemically appropriate, by their lights, to sacrifice one proposition for the greater (epistemic) good.

Here is one case of that sort. Suppose I am trying to figure out a paradox such as the liar paradox, or the lottery paradox, or one of the paradoxes that plague deontic logic. Formally, a paradox is a set of propositions that are individually plausible but jointly inconsistent. In this case, let us suppose that the paradox in question consists of three distinct propositions. Let us also suppose that all three propositions 
are equally compelling, with none an obvious candidate for the source of inconsistency. Moreover, to make the case a bit cleaner, let us stipulate that I have excellent evidence that only one of the three propositions is false: maybe my friend, who knows the solution to the paradox but wants me to figure it out for myself, has told me that only one of them is false, or maybe the overwhelming plausibility of each of the propositions is sufficient to make it extremely unlikely that more than one of them is untrue. Finally, let us fill in the story as follows: before I realized them to be incompatible, I believed all three propositions. Once their incompatibility is pointed out to me, I spend some time trying to figure out which one of them is false. After a few frustrating minutes, I think to myself, "Forget it, this philosophy stuff is too hard," and go back to believing all three propositions. The question is: am I epistemically justified, or reasonable, or rational, in doing so?

I think it is clear that I am not. What I should do is suspend judgment on the three propositions until I am able to single out one (or two) of them as the least plausible of the bunch. Then I should either suspend judgment on those propositions or outright disbelieve them, depending on the strength of my case against them. ${ }^{46}$ The problem, though, is that it is difficult to see how veritism-even a time-relative version of veritism that bans causal means - can yield this result. In going back to believing all three propositions, I take on a belief in a falsehood but also thereby come to believe two truths. From the veritist's perspective, shouldn't my failing in my epistemic aims with regard to the one false proposition be outweighed by my success in my epistemic aims with regard to the other two propositions? ${ }^{47}$

\footnotetext{
46 Some readers may think that, by insisting that I am not justified in going back to believing all three propositions, I commit myself to an implausible response to the paradox of the preface. But no such thing follows, for there are crucial disanalogies between the case at hand and the scenario envisaged in the paradox of the preface. In the preface paradox, an author of a book has, for each claim made in his or her book, some inductive evidence that the claim is false, which together give him or her excellent inductive evidence that one of the book's claims is false. In the case at hand, I have non-inductive evidence that one of three propositions is false. So to make my belief that one of these three propositions is false truly analogous to our author's prefatory remark, we'd need to consider a variant of the preface paradox in which the author's book consists of one continuous philosophical argument that eventually leads to a contradiction. But retaining belief in that book's premises and writing in its preface "At least one of the premises of this book's central argument is false since that argument leads to a contradiction" is not paradoxical; it is foolhardy.

Also, it is worth pointing out that those who think that, in the case at hand, I am justified in retaining belief in three propositions that I recognize to be inconsistent face the following dilemma: either they must give up on the idea that we can always acquire new justified beliefs by deductively reasoning from our old justified beliefs (what is known as "multipremise closure for justified belief"), or they must accept that after I go back to believing all three propositions I can become justified in believing any arbitrary proposition (since an inconsistent set of propositions entails everything). I find neither option particularly palatable.
}

47 This will not follow if a veritist holds that the disvalue of a false belief is more than twice the value of a true belief. But then we can increase the number of propositions making up our paradox to get the desired result. (To hold that a false belief is infinitely more disvaluable than a true belief is to give up on the Jamesian insight that motivated a move to two sorts of veritistic aims.) 
The lesson of this example is that even a time-relative veritist who permits only noncausal ways of promoting value must sanction implausible trade-offs between our veritistic aims with regard to different propositions. ${ }^{48}$ And another sort of example can illustrate the same lesson in an even more convincing manner, if we allow ourselves to make a certain (somewhat contentious) assumption in the philosophy of mind. The assumption in question concerns the nature of beliefs about one's own beliefs. ${ }^{49}$ Some authors - incorrectly, to my mind - think that higher-order beliefs and the lower-order beliefs featured in those higher-order beliefs are distinct existences, so that one's belief in $\langle p\rangle$ can stand in causal relations to one's belief in $<$ I believe $\langle p>>.50$ But on another account - which I favor-higher-order beliefs are partially constituted by the lower-order beliefs that they are about, and hence the relation that one's belief in $\langle p\rangle$ stands to one's belief in $\langle$ I believe $\langle p\rangle>$ is not the causal means-end relation but rather the constitutive means-end relation. ${ }^{51}$ Let us, for the time being, assume that this latter account is correct; after presenting my problem case for time-relative, noncausal veritists with such an assumption in place, I will show how it is possible to construct a similar problem case even if we reject constitutive accounts of higher-order belief.

On to the example. Suppose that, due to a quirk in my psychology, I form beliefs in a very selfconscious manner. Whenever I come to believe $\langle p\rangle$, where $\langle p\rangle$ is some claim about the external world around me, I also - at the same time - form a series of second-order beliefs about the nature of that firstorder belief and the way in which it was formed: $<\mathrm{I}$ believe $\langle p>>,<\mathrm{I}$ formed my belief in $\langle p\rangle$ on suchand-such day $>,<$ I formed my belief in $\langle p>$ using such-and-such method $>$, and so on. Moreover, for each of these second-order beliefs, I - at the same time - form a series of third-order beliefs about that second-order belief: $<$ I believe $<$ I believe $<p>>>$, $<$ I formed my belief in $<$ I believe $<p>>$ on such-andsuch day $>$, $<$ I formed my belief in $<$ I believe $<p>>$ using such-and-such method $>$, and so on. And, for

48 I think there is a clear sense in which, in the example just given, my believing the false proposition (whichever it is) is a noncausal means to my believing the two true propositions. But what sort of a noncausal means is this, exactly? Here is one proposal: my believing the false proposition is an upward constitutive means to my believing all three propositions, and my believing all three propositions is a downward constitutive means to my believing each of the two true propositions.

49 More precisely, it concerns the nature of those beliefs about one's own beliefs that are formed at least partially on the basis of introspection. I suppress this qualification in what follows.

50 The locus classicus for such a view is Armstrong 1968.

51 The locus classicus for such a view is Shoemaker 1994. 
each of these third-order beliefs, I - at the same time - form a series of fourth-order beliefs about that third-order belief: $<$ I believe $<$ I believe $<$ I believe $<p>>>>$, and so on. (Maybe this hierarchy continues a few more orders, or maybe the fourth order is where it peters out; for the purposes of my example, it doesn't matter.) Now here is the crucial thing: although I am not particularly adept at forming first-order beliefs about the external world, I am very, very good at introspection and almost always have accurate higher-order beliefs about the nature of my lower-order beliefs and the ways in which they are formed.

Now suppose that, one day, I come to believe the proposition $<$ She loves me $>$ by picking petals from a daisy while reciting, "She love me, she loves me not . . ." In forming this belief, I also come to believe $<$ I believe $<$ She loves me $>>,<$ I came to believe $<$ She loves me $>$ by picking petals from a daisy $>$, $<$ I came to believe < She loves me> on a gloriously sunny Saturday afternoon>, and so on, up the hierarchy. Since my powers of introspection are so profound, all of these higher-order beliefs are true. Now clearly my first-order belief is unjustified; if basing amatory beliefs on the outcome of petal picking is not an improper way of forming beliefs, then what is? But, given our assumption about the nature of higher-order beliefs, that first-order belief ended up being a constitutive means to forming, at the same time, a vast number of true beliefs: if $n$ is the number of higher-order beliefs that $\mathrm{I}$, in general, form about each belief of one-lower order, then my first-order belief allowed me to form $n+n^{2}+n^{3}$ true higher-order beliefs. So even a time-relative veritist who forswears causal means must deem my belief about whether she loves me to be a sacrifice for the greater epistemic good, and hence justified. ${ }^{52}$ But a better candidate for an unjustified belief is difficult to come by.

The previous example worked as it did only because we were assuming a constitutive account of the relation between higher- and lower-order beliefs. What, though, if we relax that assumption? Well, then my belief in the proposition $<$ She love me> will not be a constitutive means to my believing $<$ I believe $<$ She loves me $>>$. However, what we are concerned with here is not just whether my first-order

52 This result follows if, as most epistemic teleologists do, we are working with a satisficing deontic theory. However, Anil Gupta has pointed out to me that the result may not follow if we are working with a maximizing deontic theory since even if my belief in <She loves me> promotes a great deal of overall epistemic value, a belief instead in < She doesn't love me $>$ might promote more overall epistemic value, by better promoting epistemic value at the first-order level and promoting as much epistemic value at higher-order levels. But even if that is so, we can avoid this problem by tweaking our example a bit, so that it is built into the case that - for some reason-I would only form a hierarchy of higher-order beliefs if I believe < She loves me $>$ and not if I believe its negation. 
belief is a constitutive means to a state of affairs in which I possess a certain higher-order belief, but more importantly whether my first-order belief is a constitutive means to a state of affairs in which I possess a certain true higher-order belief. And notice that my belief in the proposition $<$ She love me $>$ is, in fact, a constitutive means to my truly believing $<$ I believe $<$ She loves me $>>$ : a state of affairs in which I truly believe $<$ I believe $<$ She loves me $>>$ is partially constituted by a state of affairs in which I believe $<$ She loves me>. Thus, regardless of what assumptions we make about the nature of higher-order beliefs, my first-order belief in < She loves me> will be a constitutive means to my having all $n$ of my true secondorder beliefs. This same strategy, though, will not work for my beliefs at the third order and higher: even if a state of affairs in which I truly believe $<$ I believe $<$ I believe $<$ She loves me $>>>$ obtains, that state of affairs is not constituted in part by my believing < She loves me $>$ if we renounce a constitutive account of higher-order beliefs. However, to get around this setback, we need only vary our example a bit: simply make all of my higher-order beliefs at the third level and beyond be about what I truly believe, rather than about what I believe. So let us suppose that, at the third level, I believe $<$ I truly believe $<$ I believe $<$ She loves me $>>>,<$ I came to truly believe $<$ I believe $<$ She loves me $>>$ through introspection $>$, etc.; that, at the fourth level, I believe $<$ I truly believe $<$ I truly believe $<$ I believe $<$ She loves me $>>>>$, etc.; and so on. Now the state of affairs in which I truly have any one of these beliefs will be partially constituted by a state of affairs in which I believe < She loves me>. The result: we have trouble even for those time-relative, noncausal veritists who are not fans of constitutive accounts of higher-order beliefs.

Therefore moving to a time-relative conception of our veritistic aims and/or excluding causal means does not avoid the basic problem for veritistic approaches to epistemic teleology. Even then, there can exist conflicts and competition between the veritist's epistemic goals with regard to different propositions. And where such conflict or competition exists, it seems that the teleologist must favor the many over the one, and thus sanction cross-propositional trade-offs. Even time-relative, noncausal veritism does not take seriously the separateness of propositions.

What about other, more complicated ways of tinkering with the details of one's teleological theory to avoid undesirable trade-offs? At this point, it is worth considering one particularly salient example in that vein, namely the process reliabilist's way of formulating a veritistic teleological theory. Two features 
of process reliabilism are pertinent here. First, process reliabilism contains an indirect deontic theory in which belief-forming processes are directly assessed in terms of how well they promote epistemic value, and individual beliefs are indirectly assessed in terms of their connection to belief-forming processes that pass a certain muster. Second, most forms of process reliabilism include a theory of overall value in which the conducing relation is restricted so that only proximate causal means are a way of promoting epistemic value: when assessing the overall epistemic value of a belief-forming process, only beliefs formed immediately by a given instantiation of that process, without the aid of any causal intermediaries, are taken to be relevant. This rules out both nonproximate causal means (such as those featured in the grant-seeking scientist case) and noncausal means (such as those featured in the paradox case and in the case of the incredibly accurate introspector) as ways of promoting epistemic value. For this reason, none of the trade-off cases I have discussed so far pose a problem for the process reliabilist.

Nevertheless, much the same dialectic as before plays out. First, the process reliabilist's restriction of the conducing relation is undermotivated, given his or her general teleological commitments. Why, exactly, are nonproximate causal means banned from being a way of promoting epistemic value, whereas proximate causal means are not? Such a fine distinction has an air of arbitrariness to it. ${ }^{33}$ But, more importantly, the features of process reliabilism that allow it to avoid some cases involving objectionable cross-propositional trade-offs do not allow it to avoid all such cases.

For example, consider the following belief-forming process. Suppose that whenever I consider whether a given natural number $n$ is prime, I form the following belief: $<n$ is not prime $>$. This process tends to yield a ratio of true to false beliefs that approaches $1 .{ }^{54}$ Thus, from the process reliabilist's perspective, my belief-forming process is almost perfectly reliable, and the false beliefs it occasionally yields are sacrifices for the (much) greater epistemic good. But when I form a belief in $<7$ is not prime $>$ on the basis of this process, I take it to be a datum that my belief is not justified (or reasonable, or rational). The lesson is that even veritists of a process-reliabilist persuasion allow illicit cross-propositional trade-offs

\footnotetext{
53 Moreover, it is worth pointing out that, in other contexts, process reliabilists are perfectly willing to allow nonproximate causal means to transmit epistemic value. In particular, the first (and, to my mind, more promising) of Goldman and Olsson's (2009) two solutions to the so-called swamping problem for process reliabilism only works if nonproximate causal means are a way of transmitting epistemic value.

54 It follows from the Prime Number Theorem that the density of primes less than $x$ approaches 0 as $x$ approaches $\infty$.
} 
between our epistemic goals, although these trade-offs occur at the level of belief-forming processes rather than at the level of individual beliefs. ${ }^{5}$

I can imagine one final, last-ditch effort on the part of the veritist. ${ }^{56}$ Perhaps, in addition to moving to a time-relative conception of epistemic value, we should also move to a proposition-relative conception of epistemic value. The idea is that a state of affairs in which I believe true proposition $<p>$ has final epistemic value relative to the proposition $\langle p\rangle$ but no epistemic value relative to any other propositions, just as - according to many ethical teleologists who are fans of time-relative value - a state of affairs in which I now murder someone has final disvalue relative to the moment of time picked out by the indexical "now" and none relative to any other time. Would revising veritism in this way allow the epistemic teleologist to avoid having to countenance cross-propositional trade-offs?

No, it would not. Relativizing the values that make up a teleologist's theory of final value in a given way does not, by itself, allow the teleologist to avoid having to countenance certain trade-offs. Rather, relativizing values only helps when, as a result of that relativization, certain cases of conflict or competition among values no longer arise. But in the case of this move to a proposition-relative conception of epistemic value, the relativization in question does not decrease the number of cases of conflicts or competition between items of final epistemic value or disvalue since one can come to believe that $p$ at the same time as one comes to, or continues to, believe that $q$ (where $\langle p\rangle$ and $\langle q\rangle$ are distinct

55 Two ways of resisting this result suggest themselves. The first is to insist that, when I come to believe that 7 is not prime, the relevant process by which my belief is formed is more narrow that the process of forming a belief in $<n$ is not prime $>$ for any natural number $n$. In a sense, this sort of response is always available to process reliabilists when faced with a putative counterexample, precisely because of another problem that bedevils their view, namely, the generality problem (see Feldman 1985; Conee and Feldman 2004 [1998]; and Feldman and Conee 2002). But such a maneuver only deflects this particular example and not the more basic problem: for any given way of specifying the narrowness or broadness of the belief-forming process that, according to process reliabilism, is relevant to the epistemic status of a given belief, it will be possible to construct problem cases with exactly the same structure as the one provided here.

The second way of resisting this case is to revise process reliabilism's deontic theory so that what matters is not just whether a belief is formed on the basis of a reliable process, but also whether there is some other belief-forming process available to the subject that, had it been used, would have resulted in that belief's not being held. (See Goldman 1992 [1979], 123.) More precisely, the suggestion is that process reliabilism's deontic subtheory for the deontic focal point \{beliefs $\}$ and the deontic property being justified be revised as follows:

S's belief that $p$ at time $t$ is justified iff (i) the belief-forming process that caused $\mathrm{S}$ to believe that $p$ at $t$ is reliable, and (ii) there is no reliable belief-forming process available to $\mathrm{S}$ that, if it had been used in addition to the process actually used, would have resulted in S's not believing that $p$ at $t$.

However, this revision helps with the case at hand only if it is true of me that there is another reliable process available to me that, if used, would result in my not believing $<7$ is not prime $>$. And we can simply stipulate that this is not true in our case. (Moreover, revising process reliabilism in the proposed manner leads to well-known problems: see BonJour 1985, 47-49; and Feldman 1985, 165-67.)

56 I thank Michael Smith for suggesting to me a version of the objection to follow. 
propositions). So even proposition-relative veritism must weigh the furtherance or frustration of our epistemic aims with regard to one proposition against the furtherance or frustration of our epistemic aims with regard to other propositions. A proposition-relative theory of final epistemic value is not a way of imposing epistemic separateness between propositions.

An analogy will help bring out the point. Suppose an ethical teleologist holds a theory according to which, in certain cases, we are morally obligated to torture one person to death in order to prevent a very large number of people from each getting a paper cut. Could the teleologist avoid this (let us assume) embarrassing result by moving to a harm-relative theory of final value according to which we have one ultimate negative goal of, with regard to the harm of torturing someone to death, not bringing about $a$ state of affairs in which someone is tortured to death and another ultimate negative goal of, with regard to the harm of receiving a paper cut, not bringing about a state of affairs in which someone receives a paper cut? No, he or she could not. Even if these goals somehow have as part of their content that they pertain only to a given harm, the two goals can be satisfied or frustrated at the same time, so altering their content in this way does not cause them to cease to be in conflict with one another in a case in which one must choose between torturing one person to death and allowing a vast number of people to each receive a paper cut. ${ }^{57}$ So, too, in the case of a move to epistemic goals that have, as part of their content, the fact that they pertain only to a given proposition: these goals can be fulfilled or frustrated at the same time, so altering their content in this way does not help the teleologist avoid having to say something about cases in which the promotion of a veritistic goal with regard to one proposition can be sacrificed in order to benefit the promotion of a vast number of veritistic goals with regard to other propositions.

This completes my case against veritistic teleological theories. To recap: Firth-style cases such as the grant-seeking scientist illustrate how the crudest forms of veritistic teleology are forced to sanction sacrificing our epistemic aims with regard to one proposition in order to further our epistemic aims with regard to many other propositions, thereby ignoring the epistemic separateness of propositions. We considered various ways of complicating a veritistic teleological theory, whether by relativizing its theory

\footnotetext{
57 A similar point holds if, rather than considering a harm-relative theory of final value, we instead consider a victim-relative theory of final value. I have chosen the former because it more vividly makes my point.
} 
of final value or by restricting the conducing relation in its theory of overall value, but none of these maneuvers managed to avoid the central problem: it was still possible to construct cases in which objectionable cross-propositional trade-offs determine the epistemic status of an individual belief. My conclusion is that any vaguely plausible variety of veritism must, in some cases, disregard the distinctness of propositions. 58

What, though, about nonveritistic teleological theories? Are they tenable? The argument I have just offered generalizes to almost all teleological epistemic theories in a fairly natural way. First, consider teleological epistemic theories that take true beliefs to have epistemic value as ends and false beliefs to have epistemic disvalue as ends, but also deem other items - such as coherent systems of belief, or understanding, or wisdom - to have epistemic value as ends. (This is, without a doubt, the most common sort of nonveritistic teleological theory found in the literature.) Since the ultimate epistemic goals countenanced by these theories include all of the ultimate epistemic goals countenanced by the veritist, my earlier argument works against these theories as well: in cases in which we can sacrifice our veritistic goal of believing the truth with regard to one proposition in order to greatly further our veritistic goals with regard to a large number of other propositions, these theories will flout the separateness of propositions by deeming such sacrifices to be epistemically appropriate. ${ }^{59}$

This leaves one last possibility: teleological theories that do not accept that true beliefs have final epistemic value and/or do not accept that false beliefs have final epistemic disvalue. For example, maybe according to such a theory it is only knowledge, or only coherent systems of belief, or only understanding, that is to be promoted as an epistemic end for its own sake. But, since in all of these theories the bearers of

58 Why the qualification "vaguely plausible"? Answer: because there are some highly implausible veritistic theories that avoid my argument. One involves restricting the conducing relation so that instantiation is the only way of promoting epistemic value. Another involves constructing a deontic theory only for the focal point \{complete systems of belief\} and not for the focal point \{beliefs\}. Against the former: then the theory's teleological structure is doing no work (and then it is forced to equate justified beliefs with true beliefs, but presumably not all true beliefs are justified). Against the latter: this is to give up on answering the question "What should I believe?" (that is, to give up on epistemically assessing individual beliefs).

59 Strictly speaking, it might turn out that, in some of these cases, an agent can only sacrifice the truth-in-belief goal with regard to the one proposition at the cost of thwarting some of his or her other, nonveritistic goals. (For example, maybe falsely believing the proposition to be sacrificed would lower the coherence of the agent's entire system of belief, but truly believing the other propositions would not raise - or would not raise as much - the coherence of his or her belief-system.) But even if this is so in some cases, it would be mind-bogglingly convenient if in every case of cross-propositional conflict between one's veritistic aims, one's nonveritistic aims exactly compensate for those conflicts. Compare: this would be like an act-utilitarian who defends a pluralist conception of well-being saying that his or her theory does not ignore the separateness of persons because in every case in which we can choose to trade one person's pain for several other people's pleasure, there are compensating losses of nonhedonic well-being for those other people (such as a loss of dignity). 
fundamental value are cognitive states that one can attain with respect to one proposition (or set of propositions, or domain of inquiry) while not attaining with respect to various other propositions (or sets of propositions, or domains of inquiry), we can run a version of my argument against such teleological theories as well.

For example, suppose our teleologist's theory of final value holds that the only items of epistemic value as ends are coherent systems of belief (where the degree of value is proportional to the degree of coherence among the beliefs), and the only items of epistemic disvalue as ends are systems of belief that lack coherence (where the degree of disvalue is proportional to the degree to which the beliefs fail to cohere with one another). The argument against this view will be almost identical to my argument against veritistic theories. The opening move will be the same: the grant-seeking scientist, for example, sacrifices coherence with regard to his or her God-related beliefs in order to greatly increase the coherence of his or her scientific beliefs. In order to avoid having to say that the scientist's belief in God's existence is epistemically justified, our teleologist might restrict the promoting value relation to rule out causal means or might move to a time-relative conception of the epistemic goal of attaining coherence (and avoiding incoherence) with regard to systems of belief. But then, just as before, there will be cases in which the coherence of one small patch of one's web of belief can be sacrificed via constitutive means in order to, at the same time, greatly increase the coherence of a large number of other patches of one's web of belief. For example, the incredibly accurate introspector slightly sacrifices the coherence of his or her romantic beliefs in order to acquire a beautifully interwoven, highly coherent fabric of beliefs about his or her own belief-forming practices on a given occasion. Thus even after the teleologist reformulates his or her theory, the basic problem remains. And so on. Because a gain in coherence in subsystem $B_{1}$ of one's belief-system can come at the cost of a loss in coherence of subsystem $B_{2}$ of one's belief-system, where these two subsystem do not contain any propositions in common, even teleological theories whose theory of final value is formulated purely in terms of coherence must sanction trade-offs that cross the boundaries between propositions. 


\section{Conclusion: Beyond Truth-Gonduciveness}

I have just argued that most teleological epistemic theories ignore the separateness of propositions and for that reason should be rejected. However, the argument I have provided so far does not-strictly speaking - apply to every possible teleological account of epistemic notions: there are moves and countermoves, ploys and counterploys, that I have not had the space to consider. But as the teleologist continues to pile on the qualifications and cobble together yet more codicils in a effort to explain away each new case involving objectionable trade-offs, I am left wanting to respond: "Sure, you can defend that qualification-heavy, codicil-ridden theory if you want to; but why would you want to? Why start with a framework whose hallmark is its propensity for trade-offs and then work so hard to erase that feature? Why not just start somewhere else?"

So let us end by considering - all too briefly - two final issues: (i) What are the alternatives to a teleological approach to normative epistemology? and (ii) What is the theoretical pay-off once we renounce the teleological approach?

First, then: what's the alternative? As it turns out, a number of nonteleological alternatives already exist in the literature, provided that we divest them of their oft-accompanying but non-essential teleological accoutrements. I mention here just two examples. First, one might defend evidentialism about epistemic justification together with a nonteleological theory of evidence. By "evidentialism," I mean (roughly) the view that belief in proposition $\langle p\rangle$ is justified for a given subject at a given time if and only if the subject's evidence at that time for and against $\langle p\rangle$ on balance supports $\langle p\rangle$. 60 When formulated in this bare-bones manner, evidentialism doesn't have much content since "evidence" is itself a normative notion, and there are many, many different theories of evidence. ${ }^{61}$ But if we plug into our evidentialist formula a nonteleological theory of evidence, then the resulting theory will be nonteleological.

\footnotetext{
60 This is close to what Earl Conee and Richard Feldman mean by "evidentialism" in a well-known series of articles defending such a view; see the papers collected in Conee and Feldman 2004, as well as Conee and Feldman 2008. Conee and Feldman occasionally appeal to teleological notions when defending their brand of evidentialism: for example, Feldman (2004 [2000], 181-86) tentatively proposes that it maximizes epistemic value to follow one's evidence, and Conee (2004 [1992], 248-51) invokes the epistemic goal of maximizing one's total stock of knowledge when discussing a particular account of the connection between epistemic justification and truth. However, both of these arguments are problematic, for precisely the sorts of reasons detailed in $\S 5$ above, and I think Conee and Feldman would be better served by jettisoning any talk of epistemic value or epistemic goals from their overall position.
}

61 For a sampling of some of the possibilities here, see Kelly 2008a and 2008b. 
My second example of a nonteleological approach to epistemic normativity can be found in the work of John Broome. For the past decade, Broome has delineated and defended a series of rational requirements that each take the form of a wide-scope principle exhorting us to have, or not to have, a certain combination of attitudes (see Broome 1999, 2001, 2005, 2007, 2008, and forthcoming). Most of these rational requirements are mixed practical/theoretical requirements, featuring both practical attitudes such as intention and theoretical attitudes such as belief; for example:

$\left(\mathrm{R}_{1}\right) \quad$ Rationality requires that [if (one intends that $e$, and one believes that it will only be the case that $e$ if it is the case that $m$, and one believes that it will only be the case that $m$ if one intends that $m$ ), then one intends that $m$ ].

However, some of Broome's rational requirements are wholly practical, such as

$\left(\mathbf{R}_{2}\right) \quad$ Rationality requires that it not be the case that [one intends to $\phi$, and one intends not to $\phi]$,

and others are wholly theoretical, such as

$\left(\mathrm{R}_{3}\right) \quad$ Rationality requires that it not be the case that [one believes that $p$, and one believes that not- $p]$.

The crucial point for my purposes is that Broome doesn't think that rationality requires us to have or not have these combinations of attitudes because doing so conduces toward something of value; rather, he just thinks that that's what rationality requires. So Broome's wholly theoretical rational requirements would count as a nonteleological approach to epistemic rationality. ${ }^{62}$

Since the two sorts of epistemic theories I have just mentioned are nonteleological in structure, it is tempting to refer to them as examples of what might be called "epistemic deontology." However, that temptation should be resisted, for two reasons. First, the name "epistemic deontology" has already been appropriated by epistemologists for another purpose. In his famous essay of the same name, William Alston (1989 [1988a], 115-18) uses the phrase "the deontological conception of epistemic justification" to refer to the view that epistemic justification can be cashed out in terms of epistemic permission, obligation, duty, responsibility, blameworthiness, or praiseworthiness. ${ }^{63}$ Now Alston's choice of terminology here is unfortunate and has led to much confusion over the years: a more faithful term for the position he was

62 Assuming, that is, that epistemic rationality just is theoretical rationality. For a contrary view, see Kelly 2003, 634-37.

63 See also Alston 1989 [1985], 84-86. 
trying to capture would be "the deontic conception of epistemic justification" ('deontic' means "pertaining to duty or obligation," whereas 'deontological' means "pertaining to the study of duty or obligation").64 Indeed, one can be an epistemic nonteleologist (in my sense) without endorsing the deontological conception of epistemic justification (in Alston's sense), ${ }^{65}$ and one can be an epistemic teleologist (in my sense) while embracing the deontological conception of epistemic justification (in Alston's sense). ${ }^{66}$ But at this point Alston's terminology is too well entrenched to resist. The second reason not to refer to nonteleological epistemic theories as examples of "epistemic deontology" is that, in my opinion, 'deontology' is no longer a useful way of designating theories, even in the ethical realm: at this point, there is such a wide array of radically different theories falling under the term 'deontology' that the time has come to stop pretending that they form a unified category. Kantianism, Rossianism, contractualism, Kamm-style nonconsequentialism, side-constraint theories, even moral particularism: all of these could, with some justification, be referred to as forms of deontology, yet they have little in common with one another other than the fact that they are not versions of consequentialism.

I have mentioned two varieties of nonteleological epistemic theories, and I have urged that they not be referred to as instances of "epistemic deontology." But regardless of what we call the nonteleological approach to epistemic normativity, does accepting that approach have any theoretical pay-off in other areas of philosophy? I believe that it does. In particular, I believe that the rejection of epistemic teleology can make a number of far-reaching problems in ethics and epistemology that currently seem intractable a bit more tractable. The teleological approach to epistemic normativity is so pervasive that, in many circles, the predicate '.. is a source of epistemic justification' has almost become synonymous with the predicate '.. is truth-conducive'. So when people ask, "Are intuitions

64 Moreover, it is simply a mistake on Alston's part to assimilate hypological notions such as responsibility, blameworthiness, and praiseworthiness and deontic notions such as permission, obligation, and duty. (The useful term 'hypological', from the Greek hypologos for 'hold accountable or liable', I owe to Michael J. Zimmerman [2002, 554].) Although it is standard to assume that deontic notions are interdefinable in a fairly straightforward manner (' $\mathrm{S}$ is obligated to $\phi$ ' being logically equivalent to ' $\mathrm{S}$ is not permitted to not $\phi$ ', and so on), the exact connection - if any - between deontic and hypological notions is a more controversial matter, whether in the case of action or belief. So really we should distinguish the deontic conception of epistemic justification from the hypological conception of epistemic justification.

65 Perhaps one is a nonteleologist who holds that epistemic justification has to do with a certain sort of fittingness (where this fittingness is not in turn analyzed in terms of a deontic modal such as 'permitted' or 'obligated').

66 Perhaps one is a teleologist who holds that ' $\ldots$ is epistemically justified' and '.. is permitted by the norms of epistemic rationality' are synonymous. 
trustworthy?," or "Do we have good reason to believe the results of reflective equilibrium?," or "Is inference to the best explanation a way of acquiring justified beliefs?," they often take these to be questions about whether the belief sources under discussion tend to result in mostly true beliefs. But showing that one of these belief sources tends to result in mostly true beliefs is extremely difficult, if not impossible, especially if we deem it illegitimately circular to appeal to that very belief source during our proof of its truth-conduciveness. For example, I think there is no hope of showing that intuitions about distinctly philosophical subject matters are truth-conducive without appealing, at some point, to other intuitions of that same sort. ${ }^{67}$ In the case of reflective equilibrium, it is now widely agreed that if you start with a sufficiently distorted set of initial considered judgments, especially your higher-order considered judgments about the comparative plausibility of your lower-order considered judgments, there is little chance that you will end up with true beliefs when you finally reach an equilibrium point (if, indeed, you ever do). ${ }^{68}$ And, finally, in the case of inference to the best explanation, if we focus just on the explanatory virtue of simplicity, the history of attempts to show that simpler theories are more likely to be true doesn't inspire one with confidence, to put it mildly. ${ }^{69} \mathrm{My}$ hope is that moving to a nonteleological conception of epistemic normativity will make it easier to show that it is epistemically appropriate to trust belief sources such as these. But that, of course, is a project for another day. ${ }^{70}$

\section{References:}

Adams, Robert Merrihew. 1976. "Motive Utilitarianism.” Journal of Philosophy 73: 467-81.

Alston, William P. 1989 [1976]. "Self-Warrant: A Neglected Form of Privileged Access." American Philosophical Quarterly 13: 257-72. Reprinted in Alston 1989, 286-315. Page references are to the

67 As, for example, George Bealer (1996a, 127; 1996b, 11; 1998, 217) does during his highly sophisticated defense of the reliability of philosophical intuitions.

68 A point made particularly forcefully by Michael DePaul (1993, 23-56; 1998, 297-98).

69 See Baker 2011 for a helpful overview.

70 In writing this essay, I have received help from an embarrassingly large number of people. Many thanks to Tyler Doggett, Stephen Grimm, Derek Parfit, Phillip Pettit, T. M. Scanlon, Drew Schroeder, Mark van Roojen, and Dennis Whitcomb for their immensely helpful written comments; to Ruth Chang, David Copp, Tom Dougherty, Catherine Elgin, Richard Feldman, Daniel Greco, Anil Gupta, Elizabeth Harman, Thomas Kelly, Niko Kolodny, John MacFarlane, Amanda Montgomery, Oded Na'aman, Ram Neta, Shantia Rahimian, Joseph Raz, Nishi Shah, Susanna Siegel, Nico Silins, Michael Smith, Daniel Star, K. L. Sylvan, Jonathan Vance, Jonathan Vogel, Gerard Vong, Robbie Williams, and Seth Yalcin for crucial discussion; to audiences at Boston University, Brandeis University, Cornell University, Leeds University, New York University, Princeton's University Center for Human Values, University of California Berkeley, University of North Carolina at Chapel Hill, University of Pittsburgh, and University of Rochester for their incisive questions; to the members of my spring 2011 graduate seminar at Harvard University for their invaluable input; and to three anonymous referees at Philosophical Review for their excellent suggestions on ways to improve the essay. 
1989 reprint.

1989 [1985]. "Concepts of Epistemic Justification." The Monist 68: 57-89. Reprinted in Alston 1989, 81-114. Page references are to the 1989 reprint.

_. 1989 [1986]. "Internalism and Externalism in Philosophy." Philosophical Topics 14: 179-221. Reprinted in Alston 1989, 185-226. Page references are to the 1989 reprint.

- 1989 [1988a]. "The Deontological Conception of Epistemic Justification.” Philosophical Perspectives 2: 257-99. Reprinted in Alston 1989, 115-52. Page references are to the 1989 reprint.

- 1989 [1988b]. “An Internalist Externalism.” Synthese 74: 265-83. Reprinted in Alston 1989, 22745. Page references are to the 1989 reprint.

- 1989. Epistemic Fustification: Essays in the Theory of Knowledge. Ithaca, NY: Cornell University Press.

- 1991. Perceiving God: The Epistemology of Religious Experience. Ithaca, NY: Cornell University Press.

- 1993. The Reliability of Sense Perception. Ithaca, NY: Cornell University Press.

- 2005. Beyond "Fustification": Dimensions of Epistemic Evaluation. Ithaca, NY: Cornell University Press.

Anderson, Elizabeth. 1993. Value in Ethics and Economics. Cambridge, MA: Harvard University Press.

Anscombe, G. E. M. 1958. "Modern Moral Philosophy." Philosophy 33: 1-19.

Armstrong, D. M. 1968. A Materialist Theory of the Mind. London: Routledge.

Baergen, Ralph. 1995. Contemporary Epistemology. Fort Worth, TX: Harcourt Brace.

Baker, Alan. 2011. "Simplicity.” In Stanford Encyclopedia of Philosophy, ed. Edward N. Zalta. Summer 2011 ed. plato.stanford.edu/archives/sum2011/entries/simplicity/.

Banner, William Augustus. 1968. Ethics: An Introduction to Moral Philosophy. New York: Charles Scribner's Sons.

Bealer, George. 1996a. "A Priori Knowledge and the Scope of Philosophy." Philosophical Studies 81: 121-42. - 1996b. "On the Possibility of Philosophical Knowledge." Philosophical Perspectives 10: 1-34.

_. 1998. "Intuition and the Autonomy of Philosophy." In DePaul and Ramsey 1998, 201-39.

Bernecker, Sven, and Duncan Pritchard, eds. 2011. The Routledge Companion to Epistemology. London: Routledge.

Blumenfeld, David, and Jean Beer Blumenfeld. 1978. "Can I Know That I Am Not Dreaming?" In Descartes: Critical and Interpretative Essays, ed. Michael Hooker, 234-55. Baltimore: Johns Hopkins University Press.

BonJour, Laurence. 1976. "The Coherence Theory of Empirical Knowledge.” Philosophical Studies 30: 281-312.

. 1978. "Can Empirical Knowledge Have a Foundation?” American Philosophical Quarterly 15: 1-13.

. 1980. "Externalist Theories of Empirical Knowledge." Midwest Studies in Philosophy 5: 53-73.

. 1985. The Structure of Empirical Knowledge. Cambridge, MA: Harvard University Press.

. 1986. "A Reconsideration of the Problem of Induction." Philosophical Topics 14: 93-124.

. 1998. In Defense of Pure Reason. Cambridge: Cambridge University Press.

. 1999a. "The Dialectic of Foundationalism and Coherentism." In The Blackwell Guide to Epistemology, ed. John Greco and Ernest Sosa, 117-42. Malden, MA: Blackwell.

. 1999b. "Foundationalism and the External World." Philosophical Perspectives 13: 229-49. 
- 2002. "Internalism and Externalism.” In Moser 2002, 234-63.

- 2003. "A Version of Internalist Foundationalism." In Laurence BonJour and Ernest Sosa, Epistemic Fustification: Internalism vs. Externalism, Foundations vs. Virtues, 3-96. Malden, MA: Blackwell.

- 2010. Epistemology: Classic Problems and Contemporary Responses. 2nd ed. Lanham, Maryland: Rowman and Littlefield.

Booth, Anthony. 2006 "Can There Be Epistemic Reasons for Action?" Grazer Philosophische Studien 73: 133-44.

—. 2008. "Deontology in Ethics and Epistemology." Metaphilosophy 39: 530-45.

Brandt, Richard B., ed. 1961. Value and Obligation: Systematic Readings in Ethics. New York: Harcourt, Brace, and World.

Broad, C. D. 1930. Five Types of Ethical Theory. London: Routledge.

Brogaard, Berit. 2009. "The Trivial Argument for Epistemic Value Pluralism, or, How I Learned to Stop Caring about Truth." In Haddock, Millar, and Pritchard 2009, 284-305.

Broome, John. 1999. "Normative Requirements.” Ratio 12: 398-419.

- 2001. "Normative Practical Reasoning." Proceedings of the Aristotelian Society Supplementary Volume 75: 175-93.

—. 2005. "Does Rationality Give Us Reasons?” Philosophical Issues 15: 321-37.

. 2007. "Requirements." In Hommage à Wlodek: Philosophical Papers Dedicated to Wlodek Rabinowicz, ed. Toni Rønnow-Rasmussen, Björn Petersson, Jonas Josefsson, and Dan Egonsson. www.fil.lu.se/hommageawlodek/site/papper/BroomeJohn.pdf (accessed September 24, 2012).

- 2008. "Is Rationality Normative?" Disputatio 11: 153-71.

. Forthcoming. Rationality through Reasoning. Oxford: Oxford University Press.

Brown, Campbell. 2011. "Consequentialize This." Ethics 121: 749-71.

Christensen, David. 2004. Putting Logic in Its Place: Formal Constraints on Rational Belief. Oxford: Oxford University Press.

Conee, Earl. 2004 [1992]. "The Truth Connection." Philosophy and Phenomenological Research 52: 657-69. Reprinted with afterword in Conee and Feldman 2004, 242-58. Page references are to the 2004 reprint.

and Richard Feldman. 2004 [1998]. "The Generality Problem for Reliabilism." Philosophical Studies 89: 1-29. Reprinted with afterword in Conee and Feldman 2004, 135-65.

and - 2004 [2001]. "Internalism Defended." In Epistemology: Internalism and Externalism, ed. Hilary Kornblith, 231-60. Malden, MA: Blackwell. Reprinted with afterword in Conee and Feldman 2004, 53-82. Page references are to the 2004 reprint.

— and - 2004. Evidentialism: Essays in Epistemology. Oxford: Oxford University Press.

and —. 2008. "Evidence." In Epistemology: New Essays, ed. Quentin Smith, 83-104. Oxford: Oxford University Press.

David, Marian. 2001. "Truth as the Epistemic Goal.” In Steup 2001, 151-69.

. 2005. "Truth as the Primary Epistemic Goal: A Working Hypothesis." In Steup and Sosa 2005, 296-312.

DePaul, Michael R. 1993. Balance and Refinement: Beyond Coherence Methods of Moral Inquiry. London: Routledge. 
—. 1998. "Why Bother with Reflective Equilibrium?” In DePaul and Ramsey 1998, 293-309.

. 2001. "Value Monism in Epistemology." In Steup 2001, 170-83.

and William Ramsey, eds. 1998. Rethinking Intuition: The Psychology of Intuition and Its Role in Philosophical Inquiry. Lanham, Maryland: Rowman and Littlefield.

Dewey, John, and James H. Tufts. 1908. Ethics. New York: Henry Holt.

Ellis, Brian. 1988. "Solving the Problem of Induction Using a Values-Based Epistemology." British Fournal for the Philosophy of Science 39: 141-60.

Feldman, Richard. 1985. "Reliability and Justification." The Monist 68: 159-74.

—. 1988. "Epistemic Obligations." Philosophical Perspectives 2: 235-56.

- 2004 [2000]. "The Ethics of Belief." Philosophy and Phenomenological Research 60: 667-95. Reprinted in Conee and Feldman 2004, 166-95. Page references are to the 2004 reprint.

—. 2002. "Epistemological Duties." In Moser 2002, 362-84.

- 2008. "Modest Deontologism in Epistemology." Synthese 161: 339-55.

- and Earl Conee. 2002. "Typing Problems." Philosophy and Phenomenological Research 65: 98-105.

Field, Hartry. 1982. "Realism and Relativism.” Journal of Philosophy 79: 553-67.

- 1998. "Epistemological Nonfactualism and the A Priority of Logic." Philosophical Studies 92: 1-24.

2000. "Apriority as an Evaluative Notion." In New Essays on the A Priori, ed. Paul Boghossian and Christopher Peacocke, 117-49. Oxford: Oxford University Press.

Firth, Roderick. 1998 [1978]. "The Schneck Lectures, Lecture 1: Epistemic Utility." In Firth 1998, $317-$ 33. First delivered as a lecture at the University of Arizona, 1978.

_. 1998 [1981]. "Epistemic Merit, Intrinsic and Instrumental." Proceedings and Addresses of the American Philosophical Association 55: 5-23. Reprinted in Firth 1998, 259-71. Page references are to the 1998 reprint.

- 1998. In Defense of Radical Empiricism: Essays and Lectures, ed. John Troyer. Lanham, Maryland: Rowman and Littlefield.

Foley, Richard. 1987. The Theory of Epistemic Rationality. Cambridge, MA: Harvard University Press.

- 1993. Working without a Net: A Study of Egocentric Epistemology. Oxford: Oxford University Press.

Frankena, William K. 1963. Ethics. 1st ed. Englewood Cliffs, NJ: Prentice-Hall.

Fumerton, Richard. 2001. "Epistemic Justification and Normativity." In Steup 2001, 49-60.

- 2002. "Theories of Justification.” In Moser 2002, 204-33.

- 2006. Epistemology. Malden, MA: Blackwell.

Garvin, Lucius. 1953. A Modern Introduction to Ethics. Boston: Houghton Mifflin.

Gauthier, David. 1962. Practical Reasoning: The Structure and Foundations of Prudential and Moral Arguments and Their Exemplification in Discourse. Oxford: Oxford University Press.

Goldman, Alvin I. 1992 [1979]. "What Is Justified Belief?" In Fustification and Knowledge, ed. George Pappas, 1-23. Dordrecht: Reidel. Reprinted in Goldman 1992, 105-26. Page references are to the 1992 reprint.

—. 1986. Epistemology and Cognition. Cambridge, MA: Harvard University Press.

- 1992. Liaisons: Philosophy Meets the Cognitive and Social Sciences. Cambridge, MA: MIT Press. 
-1999. Knoweledge in a Social World. Oxford: Oxford University Press.

- 2001. "The Unity of the Epistemic Virtues." In Virtue Epistemology: Essays on Epistemic Virtue and Responsibility, ed. Abrol Fairweather and Linda Zagzebski, 30-48. Oxford: Oxford University Press.

and Erik J. Olsson. 2009. "Reliabilism and the Value of Knowledge." In Haddock, Millar, and Pritchard 2009, 19-41.

Graham, Peter J. 2011 "Does Justification Aim at Truth?” Canadian Fournal of Philosophy 41: 51-71.

Greco, John. 1993. "Virtues and Vices of Virtue Epistemology." Canadian Fournal of Philosophy 23: 413-32.

—. 1999. "Agent Reliabilism.” Philosophical Perspectives 13: 273-96.

Grimm, Stephen R. 2008. "Epistemic Goals and Epistemic Values." Philosophy and Phenomenological Research 77: $725-744$.

_. 2009. "Epistemic Normativity." In Haddock, Millar, and Pritchard 2009, 243-64.

Haddock, Adrian, Alan Millar, and Duncan Pritchard, eds. 2009. Epistemic Value. Oxford: Oxford University Press.

Hall, Richard J., and Charles R. Johnson. 1998. "The Epistemic Duty to Seek More Evidence.” American Philosophical Quarterly 35: 129-39.

Hazlett, Allan. 2006. "How to Defeat Belief in the External World." Pacific Philosophy Quarterly 87: 198212.

- n.d. "Limning Structure as an Epistemic Goal." Unpublished manuscript.

Herman, Barbara. 1993. "Leaving Deontology Behind." In The Practice of Moral Fudgment, 208-40. Cambridge, MA: Harvard University Press.

Hieronymi, Pamela. 2006. "Controlling Attitudes.” Pacific Philosophical Quarterly 87: 45-74.

Hooker, Brad, Elinor Mason, and Dale E. Miller, eds. 2000. Morality, Rules, and Consequences: A Critical Reader. Lanham, Maryland: Rowman and Littlefield.

Howard-Snyder, Frances, and Alastair Norcross. 1993. "A Consequentialist Case for Rejecting the Right." Journal of Philosophical Research 18: 109-25.

James, William. 1897. "The Will to Believe." In The Will to Believe and Other Essays in Popular Philosophy, 131. New York: Dover.

Jenkins, C. S. 2007. "Entitlement and Rationality." Synthese 157: 25-45.

Kagan, Shelley. 2000. “Evaluative Focal Points.” In Hooker, Mason, and Miller 2000, 134-55.

Kamm, F. M. 1993. Morality, Mortality. Vol. 1, Death and Whom to Save from It. Oxford: Oxford University Press.

- 1996. Morality, Mortality. Vol. 2, Rights, Duties, and Status. Oxford: Oxford University Press.

Kelly, Thomas. 2003. "Epistemic Rationality as Instrumental Rationality: A Critique." Philosophy and Phenomenological Research 66: 612-40.

- 2008a. "Evidence." In Stanford Encyclopedia of Philosophy, ed. Edward N. Zalta. Fall 2008 ed. plato.stanford.edu/archives/fall2008/entries/evidence/.

- 2008b. "Evidence: Fundamental Concepts and the Phenomenal Conception." Philosophy Compass 3: 933-55.

Kornblith, Hilary. 1985. "Ever Since Descartes." The Monist 68: 264-76. . 1993. "Epistemic Normativity." Synthese 94: 357-76. 
- 2002. Knowledge and Its Place in Nature. Oxford: Oxford University Press.

Korsgaard, Christine M. 1983. "Two Distinctions in Goodness." Philosophical Review 92: 169-95.

- 1993. "The Reasons We Can Share: An Attack on the Distinction between Agent-Relative and Agent-Neutral Values." Social Philosophy and Policy 10: 24-51.

- 2008. The Constitution of Agency: Essays on Practical Reason and Moral Psychology. Oxford: Oxford University Press.

- 2009. Self-Constitution: Agency, Identity, and Integrity. Oxford: Oxford University Press.

Kvanvig, Jonathan. 2003. The Value of Knowledge and the Pursuit of Understanding. Cambridge: Cambridge University Press.

—. 2005. "Truth Is Not the Primary Epistemic Goal.” In Steup and Sosa 2005, 285-96.

—. 2011. "Epistemic Justification." In Bernecker and Pritchard 2011, 25-36.

Lehrer, Keith. 1977. "The Knowledge Cycle.” Noûs 11: 17-25.

—. 1981. "Self-Profile.” In Keith Lehrer, ed. Radu J. Bogdan, 3-104. Dordrecht: Reidel.

- 1988. "Coherence, Justification, and Chisholm." Philosophical Perspectives 2: 125-38.

Leplin, Jarrett. 2007. “In Defense of Reliabilism.” Philosophical Studies 134: 31-42.

- 2009. A Theory of Epistemic Fustification. Dordrecht: Springer.

Louden, Robert. 1996. "Toward a Genealogy of 'Deontology'." Journal of the History of Philosophy 34: 57192.

Lynch, Michael P. 2004. True to Life: Why Truth Matters. Cambridge, MA: MIT Press.

- 2009a. "Truth, Value, and Epistemic Expressivism." Philosophy and Phenomenological Research 79: $76-97$.

- 2009b. "The Values of Truth and the Truth of Values." In Haddock, Millar, and Pritchard 2009, 225-42.

Maitzen, Stephen. 1995. “Our Errant Epistemic Aim.” Philosophy and Phenomenological Research 55: 869-76.

McCloskey, H. J. 1957. “An Examination of Restricted Utilitarianism.” Philosophical Review 66: 466-85.

Miscevic, Nenad. 2007. "Virtue-Based Epistemology and the Centrality of Truth (Towards a Strong Virtue-Epistemology)." Acta Analytica 22: 239-66.

Montmarquet, James. 1987. "Epistemic Virtue.” Mind 96: 482-97.

- 1993. Epistemic Virtue and Doxastic Responsibility. Lanham, Maryland: Rowman and Littlefield.

—. 2008. "Virtue and Voluntarism." Synthese 161: 393-402.

Moser, Paul K. 1985. Empirical fustification. Dordrecht: Reidel.

— ed. 2002. The Oxford Handbook of Epistemology. Oxford: Oxford University Press.

Muirhead, John H. 1932. Rule and End in Morals. London: Oxford University Press.

Nagel, Thomas. 1970. The Possibility of Altruism. Princeton, NJ: Princeton University Press.

Norcross, Alastair. 2006a. "Reasons without Demands: Rethinking Rightness." In Contemporary Debates in Moral Theory, ed. James Dreier, 38-53. Malden, MA: Blackwell.

- 2006b. "The Scalar Approach to Utilitarianism." In The Blackwell Guide to Mill's Utilitarianism, ed. Henry R. West, 217-32. Malden, MA: Blackwell.

Nozick, Robert. 1974. Anarchy, State, and Utopia. New York: Basic Books. 
Percival, Philip. 2002. "Epistemic Consequentialism." Proceedings of the Aristotelian Society Supplementary Volume $76: 121-51$.

Pettit, Philip. 1991. "Consequentialism.” In A Companion to Ethics, ed. Peter Singer, 230-40. Malden, MA: Blackwell.

. 1997. "The Consequentialist Perspective." In Marcia Baron, Philip Pettit, and Michael Slote, Three Methods of Ethics: A Debate, 92-174. Malden, MA: Blackwell.

_ and Michael Smith. 2000. "Global Consequentialism.” In Hooker, Mason, and Miller 2000, 12133.

Piller, Christian. 2009. "Desiring the Truth and Nothing but the Truth.” Noûs 43: 193-213.

Pippin, Robert. 2001. “A Mandatory Reading of Kant's Ethics?” Philosophical Quarterly 51: 386-93.

Plantinga, Alvin. 1988. "Positive Epistemic Status and Proper Function." Philosophical Perspectives 2: 1-50.

- 1993a. Warrant: The Current Debate. Oxford: Oxford University Press.

- 1993b. Warrant and Proper Function. Oxford: Oxford University Press.

Portmore, Douglas. 2008. "Dual-Ranking Act-Consequentialism.” Philosophical Studies 138: 409-27.

_. 2011. "The Teleological Conception of Practical Reasons." Mind 120: 117-53.

Rawls, John. 1963. "Constitutional Liberty and the Concept of Justice." Nomos 6: 98-125.

- 1971. A Theory of Justice, original ed. Cambridge, MA: Harvard University Press.

Reynolds, Steven L. 2002. "Testimony, Knowledge, and Epistemic Goals.” Philosophical Studies 110: 13961.

Ridge, Michael. 2009. "Kantian Consequentialism.” Philosophical Perspectives 23: 421-38.

Riggs, Wayne D. 2002. "Beyond Truth and Falsehood: The Real Value of Knowing That p." Philosophical Studies 107: 87-108.

—. 2003. "Balancing Our Epistemic Goods." Noûs 37: 342-52.

_. 2008a. "Epistemic Risk and Relativism." Acta Analytica 23: 1-8.

- 2008b. "The Value Turn in Epistemology." In New Waves in Epistemology, ed. Vincent F. Hendricks and Duncan Pritchard, 300-323. New York: Palgrave Macmillan.

Rowbottom, Darrell. 2008. "An Alternative Account of Epistemic Reasons for Action: In Response to Booth." Grazer Philosophische Studien 76: 191-98.

Scanlon, T. M. 1998. What We Owe to Each Other. Cambridge, MA: Harvard University Press.

—. 2002. "Replies." Social Theory and Practice 28: 337-58.

Scheffler, Samuel, ed. 1988. Consequentialism and Its Critics. Oxford: Oxford University Press.

Schmitt, Frederick. 1992. Knowledge and Belief. London: Routledge.

—. 2000. "Veritistic Value." Social Epistemology 14: 259-80.

Shoemaker, Sydney. 1994. "Self-Knowledge and 'Inner Sense', Lecture 2: The Broad Perceptual Model." Philosophy and Phenomenological Research 54: 271-90.

Shogenji, Tomoji. 2012a. "The Degree of Epistemic Justification and the Conjunction Fallacy." Synthese 184: 29-48.

—. 2012b. "Internalism and Externalism in Meliorative Epistemology." Erkenntnis 76: 59-72.

Sider, Ted. 1993. "Asymmetry and Self-Sacrifice.” Philosophical Studies 70: 117-32. 
Slote, Michael. 1985. Common-Sense Morality and Consequentialism. Boston: Routledge and Kegan Paul.

Sosa, Ernest. 1991. Knowledge in Perspective: Selected Essays in Epistemology. Cambridge: Cambridge University Press.

Steglich-Petersen, Asbjørn. 2009. "Weighing the Aim of Belief." Philosophical Studies 145: 395-405.

- 2011. "How to Be a Teleologist about Epistemic Reasons." In Reasons for Belief, ed. Andrew Reisner and Asbjørn Steglich-Petersen, 13-33. Cambridge: Cambridge University Press.

_. n.d. "Truth as the Aim of Epistemic Justification." Unpublished manuscript.

Steup, Matthias, ed. 2001. Knoweledge, Truth, and Duty: Essays on Epistemic Fustification, Responsibility, and Virtue. Oxford: Oxford University Press.

- and Ernest Sosa, eds. 2005. Contemporary Debates in Epistemology. Malden, MA: Blackwell.

Thomson, Judith Jarvis. 1976. "Killing, Letting Die, and the Trolley Problem.” The Monist 59: 204-17.

Tsanoff, Radoslav A. 1947. Ethics. New York: Harper and Brothers.

Vahid, Hamid. 2006. "Aiming at Truth: Doxastic vs. Epistemic Goals." Philosophical Studies 131: 303-35.

. 2010. "Rationalizing Beliefs: Evidential vs. Pragmatic Reasons.” Synthese 176: 447-62.

- 2011. "The Concept of Entitlement and Its Epistemic Relevance." Pacific Philosophy Quarterly 92: 380-99.

Velleman, David. 2000a. "On the Aim of Belief.” In Velleman 2000b, 244-81.

- 2000b. The Possibility of Practical Reason. Oxford: Oxford University Press.

- 2009. How We Get Along. Cambridge: Cambridge University Press.

Wedgwood, Ralph. 2002. "The Aim of Belief.” Philosophical Perspectives 16: 267-97.

—. 2008. "Contextualism about Justified Belief.” Philosophers' Imprint 8 (9): 1-20.

Weinberg, Jonathan M. 2007. "Moderate Epistemic Relativism and Our Epistemic Goals." Episteme 4: 66-92.

Whitcomb, Dennis. 2007. "An Epistemic Value Theory.” PhD diss., Rutgers University.

—. 2011. "Wisdom." In Bernecker and Pritchard 2011, 95-105.

Willenken, Tim. 2012. "Deontic Cycling and the Structure of Commonsense Morality." Ethics 122: 54561.

Williams, Bernard. 1973a [1970]. "Deciding to Believe." In Language, Belief, and Metaphysics, ed. Howard E. Kiefer and Milton K. Munitz. Albany: State University of NY Press, 95-111. Reprinted in Williams 1973a, 136-51. Page references are to the 1973 reprint.

—. 1973a. Problems of the Self: Philosophical Papers 1956-1972. Cambridge: Cambridge University Press.

_. 1973b. "A Critique of Utilitarianism." In J. J. C. Smart and Bernard Williams, Utilitarianism: For and Against, 75-150. Cambridge: Cambridge University Press.

Zimmerman, Michael J. 2002. "Taking Luck Seriously.” Gournal of Philosophy 99: 553-76.

Zink, Sidney. 1962. The Concepts of Ethics. London: MacMillan and Co. 